Final Report

FHWA/IN/JTRP-2004/36

\title{
REMEDIATION AND STABILIZATION OF SOILS CONTAMINATED BY LEAD RESULTING FROM THE REMOVAL OF PAINT FROM BRIDGES
}

\author{
by \\ M. Katherine Banks \\ School of Civil Engineering \\ Purdue University \\ A. Paul Schwab \\ Department of Agronomy \\ Purdue University \\ Joint Transportation Research Program \\ Project No. C-36-68M \\ File No. 4-7-13 \\ SPR-2457

\begin{abstract}
Conducted in Cooperation with the
Indiana Department of Transportation

Federal Highway Administration
\end{abstract} \\ and the U.S. Department of Transportation
}

The contents of this report reflect the views of the authors who are responsible for the facts and the accuracy of the data presented herein. The contents do not necessarily reflect the official views or policies of the Indiana Department of Transportation or the Federal Highway Administration at the time of publication. This report does not constitute a standard, specification, or regulation.

School of Civil Engineering

Purdue University

July 2005 


\section{TECHNICAL Summary}

INDOT Research

Technology Transfer and Project Implementation Information

TRB Subject Code: 23-8 Ecological Abatement

Publication No.: FHWA/IN/JTRP-2004/36, SPR-2457

July 2005

Final Report

\section{Remediation and Stabilization of Soils Contaminated by Lead Resulting from the Removal of Paint from Bridges}

\section{Introduction}

Lead-based paints are commonly used on steel bridge structures. Soils in the immediate vicinity of older bridges have been found to be contaminated with $\mathrm{Pb}$ as a result of normal weathering and peeling of the paint coupled with paint removal prior to repainting. The extent of the lead-bearing paint problem is quite extensive in the United States. Approximately 300,000 highway and railroad bridges bear lead paint, and approximately 16,000 are repainted each year. Processes used to remove paint from older structures will result in lead-containing dust and chips to be dispersed in the immediate vicinity and elevate soil concentrations. Levels in soil from peeling paint and paint removal as high as 20,000 $\mathrm{mg} \mathrm{Pb} / \mathrm{kg}$ soil have been reported.

Environmental guidelines are in place that regulate the handling of lead contaminated soils. The U.S. EPA is concerned about $\mathrm{Pb}$ in demolition debris and soil, and new provisions have been enacted. For example, the U.S. EPA has set the maximum concentrations to $400 \mathrm{mg} \mathrm{Pb} / \mathrm{kg}$ for residential areas where children play, and 1200 $\mathrm{mg} / \mathrm{kg}$ for other soils. Indiana regulations are 400 $\mathrm{mg} / \mathrm{kg}$ for residential and $1000 \mathrm{mg} / \mathrm{kg}$ for industrial uses.

The accumulation of lead-bearing paint residues in soils near highway bridges in combination with state and federal regulations dictate that $\mathrm{Pb}$ contaminated soils eventually must be remediated. Typical options, including excavation, capping, and soil washing, often are expensive and can present logistical problems. An in-place, low cost approach to remediating these soils would allow INDOT to address the problem and meet regulatory expectations with minimal cost.

The goal of this project was to test the use of phytoremediation and phosphate addition as mechanisms of meeting regulatory requirements for soils contaminated by Pb-based paints from highway bridges.

\section{Findings}

The specific objectives of this study were to 1) Assess the extent of $\mathrm{Pb}$ contamination of soils near selected bridges. 2) Evaluate the use of phytoremediation directly on these soils to determine the efficacy of this technology. 3) Apply phosphate to $\mathrm{Pb}$-contaminated soils to determine the effect on the $\mathrm{Pb}$ stability. 4) Evaluate through supporting laboratory studies if addition of phosphate decreases lead mobility in soil. 5) Compare the costs of remediation alternatives.

Approximately 20 bridges were surveyed statewide to assess potentially elevated concentrations of $\mathrm{Pb}$ in soil and to determine the extent of any contamination present. Soils near two bridges were found to have greater than $1400 \mathrm{mg} / \mathrm{kg}$ over a significant area, and these were chosen for complete assessment in the field and laboratory.

The major findings of this project were: a) $\mathrm{Pb}$ contamination was found in the immediate vicinity of recently painted bridges, but soil concentrations were generally less than $400 \mathrm{mg} / \mathrm{kg}$. Three of twenty bridges examined had extensive contamination greater than $1000 \mathrm{mg} / \mathrm{kg}$. b) Phosphate additions were effective in significantly reducing bioaccessible $\mathrm{Pb}$. c) Sunflowers were unable to remove $\mathrm{Pb}$ from the soils. d) A column study of contaminated soil demonstrated the very low mobility of $\mathrm{Pb}$ in soils. e) Immobilization of $\mathrm{Pb}$ with soluble phosphate will cost less than half of 
traditional remediation approaches, and possibly as little as one-tenth.

The recommendation from this study is that the immediate vicinity of recently painted bridges be tested for $\mathrm{Pb}$ in the soils. Elevated concentrations can be treated with soluble phosphate to reduce bioavailability of $\mathrm{Pb}$. This approach will offer environmental protection at a low cost.

\section{Implementation}

Our research project demonstrated that the extent of $\mathrm{Pb}$ contamination in the vicinity of highway bridges is not as large a problem as originally feared. However, some significant contamination exists near some bridges, and this contamination should be addressed. Our recommendation is to sample the soil around the bridge in question, extending at least 150 feet in all directions from the boundaries of the bridge. Those areas with concentrations greater than $400 \mathrm{mg} / \mathrm{kg}$ should be remediated. In our evaluation, the least expensive and most effective approach (other than complete excavation) is to treat the impacted area with soluble phosphorus. A ratio of 3 parts $\mathrm{P}$ to 1 part $\mathrm{Pb}$ (molar basis) is recommended, and the $\mathrm{P}$ should be incorporated into the soil to a depth of $5 \mathrm{~cm}$ if possible. After approximately one year, the soils should be resampled and tested to determine the efficacy of the remediation.

\section{Contacts}

For more information:

Prof. M. Katherine Banks

Principal Investigator

School of Civil Engineering

Purdue University

West Lafayette IN 47907

Phone: (765) 496-3424

Fax: (765) 496-1107

E-mail: kbanks@ecn.purdue.edu

Prof. A. Paul Schwab

Principal Investigator

Department of Agronomy

Purdue University

West Lafayette IN 47907

Phone: (765) 496-3602

Fax: (765) 496-2926

E-mail: pschwab@purdue.edu
Indiana Department of Transportation

Division of Research

1205 Montgomery Street

P.O. Box 2279

West Lafayette, IN 47906

Phone: (765) 463-1521

Fax: (765) 497-1665

Purdue University

Joint Transportation Research Program

School of Civil Engineering

West Lafayette, IN 47907

Phone: (765) 494-9310

Fax: (765) 496-7996

jtrp@ecn.purdue.edu

http://www.purdue.edu/jtrp 


\begin{tabular}{|c|c|c|}
\hline $\begin{array}{l}\text { 1. } \text { Report No. } \\
\text { FHWA/IN/JTRP-2004/36 }\end{array}$ & 2. Government Accession No. & 3. Recipient's Catalog No. \\
\hline \multirow{2}{*}{\multicolumn{2}{|c|}{$\begin{array}{l}\text { 4. Title and Subtitle } \\
\text { Remediation and Stabilization of Soils Contaminated by Lead } \\
\text { Resulting from the Removal of Paint from Bridges }\end{array}$}} & $\begin{array}{l}\text { 5. } \quad \text { Report Date } \\
\text { Julyt } 2005\end{array}$ \\
\hline & & 6. Performing Organization Code \\
\hline \multicolumn{2}{|c|}{$\begin{array}{l}\text { 7. Author(s) } \\
\text { M. Katherine Banks and A. Paul Schwab }\end{array}$} & 8. Performing Organization Report No. \\
\hline \multirow{2}{*}{\multicolumn{2}{|c|}{$\begin{array}{l}\text { 9. Performing Organization Name and Address } \\
\text { Joint Transportation Research Program } \\
550 \text { Stadium Mall Drive } \\
\text { Purdue University } \\
\text { West Lafayette, IN } 47907\end{array}$}} & 10. Work Unit No. \\
\hline & & $\begin{array}{l}\text { 11. Contract or Grant No. } \\
\text { SPR-2457 }\end{array}$ \\
\hline \multirow{2}{*}{\multicolumn{2}{|c|}{$\begin{array}{l}\text { 12. Sponsoring Agency Name and Address } \\
\text { Indiana Department of Transportation } \\
\text { State Office Building } \\
100 \text { North Senate Avenue } \\
\text { Indianapolis, IN } 46204\end{array}$}} & $\begin{array}{l}\text { 13. Type of Report and Period Covered } \\
\text { Final Report }\end{array}$ \\
\hline & & 14. Sponsoring Agency Code \\
\hline
\end{tabular}

15. Supplementary Notes

Prepared in cooperation with the Indiana Department of Transportation and Federal Highway Administration.

\section{Abstract}

Lead-based paints are commonly used for painting steel bridge structures. Soils in the immediate vicinity of older bridges have been contaminated with $\mathrm{Pb}$ as a result of normal weathering and peeling of the paint coupled with removal prior to repainting. The objectives of this project were to assess the extent of lead contamination near highway bridges and to evaluate phytoremediation and immobilization as means of remediation. We examined soils in the vicinity of approximately 20 bridges in Indiana that had been repainted recently and were know to have been painted originally with Pb-based paint. We found only three bridges in which the extensive areas of soil were contaminated by $\mathrm{Pb}$ in concentrations greater than 400 $\mathrm{mg} / \mathrm{kg}$. Two of these sites were used for this project. In the field study, soluble phosphate was added to the soil and transformations of $\mathrm{Pb}$ were monitored using chemical extractants. Simultaneously, sunflowers were grown in the field to test the feasibility of phytoextraction for these conditions. Phosphate additions were effective in significantly reducing bioaccessible $\mathrm{Pb}$, but the sunflowers were unable to remove $\mathrm{Pb}$ from the soils. A laboratory study using columns of contaminated demonstrated the very low mobility of $\mathrm{Pb}$ in soils. The recommendation from this study is that the immediate vicinity of recently painted bridges be tested for $\mathrm{Pb}$ in the soils. Elevated concentrations can be treated with soluble phosphate to reduce bioavailability of $\mathrm{Pb}$.

\begin{tabular}{|c|c|c|c|c|}
\hline \multicolumn{2}{|c|}{$\begin{array}{l}\text { 17. Key Words } \\
\text { Lead, highway bridges, soil, contamination, paint, } \\
\text { bioaccessibility, bioavailability, phosphate, } \\
\text { phytoremediation. }\end{array}$} & \multicolumn{3}{|c|}{$\begin{array}{l}\text { 18. Distribution Statement } \\
\text { No restrictions. This document is available to the public through the } \\
\text { National Technical Information Service, Springfield, VA } 22161\end{array}$} \\
\hline $\begin{array}{l}\text { 19. Security Classif. (of this report) } \\
\text { Unclassified }\end{array}$ & \multicolumn{2}{|c|}{$\begin{array}{c}\text { 20. Security Classif. (of this page) } \\
\text { Unclassified }\end{array}$} & $\begin{array}{r}\text { 21. No. of Pages } \\
25\end{array}$ & 22. Price \\
\hline
\end{tabular}




\section{INTRODUCTION AND PROBLEM STATEMENT}

Lead-based paints were commonly used for painting steel bridge structures. Soils in the immediate vicinity of older bridges have been contaminated with $\mathrm{Pb}$ as a result of normal weathering and peeling of the paint coupled with removal prior to repainting. The extent of the lead-bearing paint problem is quite extensive in the United States. Approximately 300,000 highway and railroad bridges bear lead paint (Steel Structures Painting Council, 1991), and approximately 16,000 are repainted each year. Processes used to remove paint from older structures will result in lead-containing dust and chips to be dispersed in the immediate vicinity and elevate soil concentrations. Levels in soil from peeling paint and paint removal as high as 20,000 mg Pb/kg soil have been reported (Grohse et al., 1992).

A survey for $\mathrm{Pb}$ in soils was conducted near a bridge at Sydney Harbor in Australia to determine the concentrations as a function of distance from the bridge. The concentrations of lead in the soil near the bridge were elevated $(>1,000 \mathrm{mg} / \mathrm{kg})$ and appear to have been a reflection of lead-based paint. The data are not conclusive due to the elevated background concentrations resulting from a smelter in the region and high vehicular traffic.

Environmental regulations are in place that impact lead contaminated soils. The U.S. EPA is concerned about $\mathrm{Pb}$ in demolition debris and soil, and new provisions have been enacted (U.S. Environmental Protection Agency, 2001). For example, the U.S. EPA has set the maximum concentrations to $400 \mathrm{mg} \mathrm{Pb} / \mathrm{kg}$ for residential areas where children play, and $1200 \mathrm{mg} / \mathrm{kg}$ for other soils. The Indiana Department of Environmental Management (1996) proposed similar Tier II levels in a nonrule policy document:

Residential surface and subsurface soils: $400 \mathrm{ppm}$ total lead; or TCLP* non-detect; and all exposed soil shall be capped with at least a 6 inch barrier in the form of sod, pavement, etc. Nonresidential surface and subsurface soils: 1000 ppm total lead; or TCLP non-detect; and all exposed soil shall be capped with at least a 6 inch barrier in the form of sod, pavement, etc.

(*TCLP is the Toxicity Characteristic Leaching Procedure, Kimmel 1988.)

The accumulation of lead-bearing paint residues in soils near highway bridges in combination with state and federal regulations dictate that the $\mathrm{Pb}$ contaminated soils eventually must be remediated. Typical options, including excavation, capping, and soil washing, often are expensive and can present logistical problems. An in-place, low cost approach to remediating these soils would allow INDOT to address the problem and meet regulatory expectations with minimal cost.

Two technologies have emerged in the past decade that could greatly benefit the State of Indiana's solution to $\mathrm{Pb}$ lead contamination near highway bridges. Phytoremediation is the use of higher plants to alleviate contamination problems. Plant species have been identified that have the capacity to accumulate very high concentrations of lead from contaminated soils. Brassica junacea and Thlaspi caerulescens have been reported with plant tissue concentrations of greater than $500 \mathrm{mg} \mathrm{Pb} / \mathrm{kg}$ compared to $<100 \mathrm{mg} / \mathrm{kg}$ for non-accumulating plant species as shown in Table 1 (Wu et al., 1999; Baker et al., 1994). The speculation is that these species could be planted in $\mathrm{Pb}$ contaminated soils, and the $\mathrm{Pb}$ will be extracted from the soil and into the aboveground tissue (Wang et al., 1986).

The second technology that could impact remediation of soils contaminated by $\mathrm{Pb}$ bearing paint is the immobilization of the metal using soluble phosphate. Lead phosphate, particularly the mineral chloropyromorphite, is highly insoluble and has significantly reduces $\mathrm{Pb}$ leachability and bioavailability (Zhang and Ryan, 1998). Additions of phosphate can reduce the 
risks associated with $\mathrm{Pb}$ contamination and help soils meet TCLP requirements (Chen et al, 1997; Bruell et al., 1999).

Table 1. Mean $\mathrm{Pb}$ concentrations in soils and in plant tissues of Thlaspi caerulescens from several sites in the United Kingdom (Baker et al., 1994).

\begin{tabular}{|c|c|c|c|}
\hline Element & Soil (total) & Plant shoots & Accumulation factor* \\
\hline & --- & & \\
\hline \multirow[t]{6}{*}{$\mathrm{Pb}$} & 90,300 & 662 & 0.007 \\
\hline & 11,800 & 203 & 0.017 \\
\hline & 11,900 & 203 & 0.017 \\
\hline & 51,600 & 166 & 0.003 \\
\hline & 6,920 & 57 & 0.008 \\
\hline & 15,500 & 222 & 0.014 \\
\hline
\end{tabular}

* Ratio of $\mathrm{Pb}$ in the plants to $\mathrm{Pb}$ in the soil

\section{OBJECTIVES}

The overall goal of this project is to test the use of phytoremediation and phosphate addition as mechanisms of meeting regulatory requirements for soils contaminated by Pb-based paints from highway bridges. The specific objectives are:

1. Assess the extent of $\mathrm{Pb}$ contamination of soils near selected bridges. The bridges should be of the proper age with a maintenance record that would lead to significant impact of Pb-based paint on adjacent soils

2. Evaluate the use of phytoremediation directly on these soils to determine the efficacy of this technology.

3. Apply phosphate to Pb-contaminated soils to determine the effect on the Pb stability, particularly with regard to TCLP concentrations. Evaluate through supporting laboratory studies if addition of phosphate decreases lead mobility in soil.

4. Throughout the project, conduct cost comparisons between the treatments under investigation and conventional remediation (excavation and burial). These cost comparisons will include both capital and operating costs.

\section{APPROACH}

The project was executed in three phases. The first phase consisted of locating prospective sites and characterizing concentrations of $\mathrm{Pb}$ over the immediate area. The second phase, involved adding soluble phosphate to immobilize $\mathrm{Pb}$ and establishing $\mathrm{Pb}$ hyperaccumulating plants on the most contaminated soils and measure $\mathrm{Pb}$ removal by these plants. The third phase was a laboratory column study to evaluate the impact of added phosphate $\mathrm{Pb}$ mobility.

\section{Site selection and characterization.}

The first several months of this project were spent finding and evaluating potential sites. The first step was accessing information from the INDOT database concerning recently painted bridges that were of sufficient age to potentially have an undercoating of Pb-based paint. We found 
approximately 20 bridges that fit this scenario, and they were fairly evenly distributed across the state. Because our goal was to find 3 suitable sites, our strategy was to begin examining the bridges closest to West Lafayette and worked our way across the state. We visited approximately 15 of the 20 sites, with the farthest away being the West Harrison bridge (near the Indiana-Ohio border) and three bridges near Terre Haute. The sites were characterized by systematically measuring soil- $\mathrm{Pb}$ concentrations in the soil using a Niton x-ray fluorescence spectrometer. A given site was retained for further study if more than $400 \mathrm{~m}^{2}$ of exposed soil had concentrations greater than $300 \mathrm{mg} / \mathrm{kg}$.

\section{Field Site Establishment.}

Three sites were selected for this study: 1) The area west of the Wabash River on State Highway 43 under the US 52 overpass. 2) The median on I-65, south of the bridge for County Road 200N (south of Lafayette in Tippecanoe County). 3) The area under the West Harrison bridge, located over the Whitewater River near the eastern terminus of State Highway 46 in Dearborn County. Each area had elevated $\mathrm{Pb}$ concentrations, though the concentrations were highly variable (see Appendix).

Site Preparation The West Harrison bridge site was lost to flooding and associated sediment erosion. Extended periods of very high water eroded all the contaminated sediments. This site was eliminated from the program and was not replaced.

The remaining two sites were subdivided into three subplots, 25 feet long and 6 feet wide. One subplot was used for P additions, one for sunflowers only (see below), and one for sunflowers $+P$. The vegetation at each site was maintained as it was found. The grass in the median of I-65 was not removed; the area under the Highway 52 bridge was essentially devoid of vegetation and was left that way except in the areas planted with sunflowers.

Phosphorus Fertilization The objective of this phase of the research was to test the capacity of soluble $\mathrm{P}$ to immobilize $\mathrm{Pb}$ in contaminated soil. Phosphorus was added to the contaminated sites at a mole ratio of 3:1 P:Pb. Depending upon the weighted average concentration for a given plot, this resulted in approximately $180 \mathrm{mg}$ P/ha (200 lb/acre). Pelletized diammonium phosphate was broadcast over each plot designated to receive $\mathrm{P}$, and the $\mathrm{P}$ was raked into the soil by hand. The fertilizer was allowed to incubate in the soil for 2 weeks prior to seeding with sunflowers to avoid salt damage.

Sunflower Establishment Sunflowers (Helianthus annuus) were planted in the designated plots in the May, 2002. The seeds were sown by hand to a depth of $2.5 \mathrm{~cm}$ (1 inch), $30 \mathrm{~cm}$ apart, and with row spacings of $30 \mathrm{~cm}$. Helianthus annuus was chosen because it grows well in central Indiana and has good capabilities for removing metals from soils. Emergence and growth were good on I-65 plots (Fig. 1), but growth was poor under the bridge of Highway 52. Poor growth in this area was a combination of the highway blocking nearly all rainfall as well as diminished sunlight. 


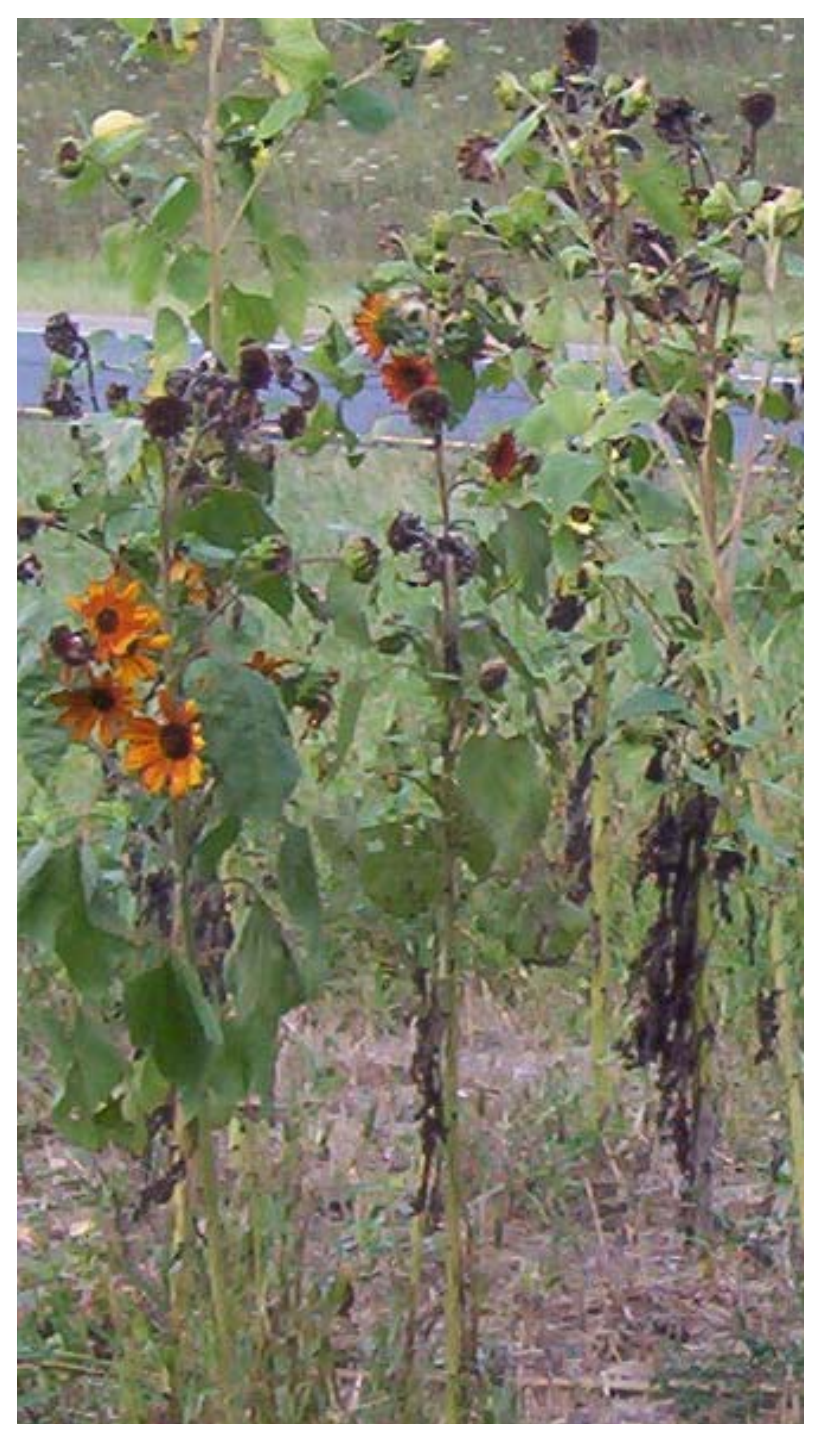

Figure 1. Sunflowers growing at the I-65 and County Road 200N.

\section{Soil Analyses}

$\underline{\text { Total Pb }}$ The method used was developed by Sposito et al. (1982) and is not a true "total" digestion. The procedure is a strong acid digestion method that dissolves almost all elements that could be environmentally available, but elements bound to silicate structures will not be dissolved by this procedure. Two grams of soil are mixed with $12.5 \mathrm{~mL}$ of $4 \mathrm{MHNO}$, in digestion vessels. The samples are heated at $80^{\circ} \mathrm{C}$ for 16 hours then filtered and analyzed $\mathrm{Pb}$ by GFAA.

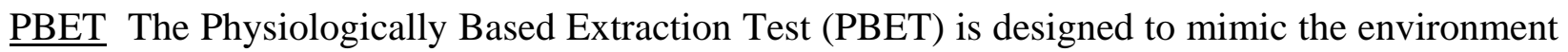
of the human stomach when soil is ingested. The extraction fluid is prepared using reagent grade solutions. Glycine (60.06 g; G48-500 Fisher Scientific) is added to 1.9 L of DI water. This extraction fluid is heated in a water bath to $37^{\circ} \mathrm{C}$. Hydrochloric acid is added until solution reaches $\mathrm{pH}$ of $1.5 \pm 0.05$ ( $\mathrm{pH}$ meter is calibrated with buffer solutions that also are heated to $37^{\circ} \mathrm{C}$ ). The volume of the solution is brought to $2 \mathrm{~L}$ (creating $0.4 \mathrm{M}$ glycine). 
Approximately $100 \mathrm{~mL}( \pm 0.5 \mathrm{~mL})$ of extraction fluid is transferred to a tared $125 \mathrm{~mL}$ plastic bottle and $1.00 \mathrm{~g}( \pm 0.005 \mathrm{~g})$ of soil is added (the final weight of the sample added is recorded). Bottles are hand tightened and checked for leakage. Bottles are placed in a shaker (Fig. 3). Samples are rotated for 1 hour at $30 \mathrm{rpm}$, removed, dried, and placed upright on a lab bench. A $14.5 \mathrm{~mL}$ aliquot of the resulting extract is filtered through a $20 \mu \mathrm{m}$ cellulose acetate disk, syringe filter into a $15 \mathrm{~mL}$ centrifuged tube. If the extract is cloudy and it is not possible to filter $10 \mathrm{~mL}$ of the extract, a sample will be centrifuged for 2 minutes and then filtered. Filtered extract will be acidified with $0.5 \mathrm{~mL}$ concentrated nitric acid and stored in a refrigerator, $4^{\circ} \mathrm{C}$, until analysis. Analysis for will be performed by GFAA. The time between the end of the extraction on the shaker and filtration must be less than 90 minutes or the test will be repeated. The $\mathrm{pH}$ of the remaining extract will be measured in the sample bottle. If the fluid $\mathrm{pH}$ was not within $\pm 0.5 \mathrm{pH}$ units of the starting $\mathrm{pH}$, the test was discarded and the sample analyzed in the following way: 1) If the $\mathrm{pH}$ dropped by 0.5 or more $\mathrm{pH}$ units, test was repeated in the same fashion as described above. In the repeated test, if the $\mathrm{pH}$ also dropped by 0.5 or more $\mathrm{pH}$ units, the $\mathrm{pH}$ will be recorded and extract filtered for analysis. 2) If the $\mathrm{pH}$ increased by 0.5 or more $\mathrm{pH}$ units, the test must be repeated in the same fashion as described above, except while the sample is shaken it must be stopped at specific time intervals and $\mathrm{pH}$ is adjusted manually to 1.5 by dropwise addition of $\mathrm{HCl}$ (adjustments at 5, 10, 15 and 30 minutes into the extract and upon final removal from water bath after 60 minutes).

For quality assurance, a reagent blank was analyzed once per batch. Blanks spiked with $10 \mathrm{mg} / \mathrm{L}$ of lead were run every 20 samples. All samples were run in triplicates.

\section{Laboratory Column Leaching Studies.}

Column Construction and Leaching

In support of the field research described previously, a column study was conducted. Eight cylindrical columns (PVC: $10 \mathrm{~cm}$ diameter by $45 \mathrm{~cm}$ length) were constructed. The bottom of each column was fitted with a threaded endcap with a $0.5 \mathrm{~cm}$ inside diameter outlet for water flow (Fig. 2). Approximately $1 \mathrm{~cm}$ of glass wool was packed into the bottom of the column to prevent soil loss. This was followed by $1 \mathrm{~cm}$ of acid-washed soil, and the column was filled with soil. The bottom $28 \mathrm{~cm}$ of the column was filled with clean subsoil from the proper site. Contaminated soil was placed on top of the subsoil to a depth of $14 \mathrm{~cm}$, leaving a headspace of 3 $\mathrm{cm}$ at the top of each column. The preparation of the topsoil comprised the treatments: 1) uncontaminated topsoil (control); 2) unamended, Pb-contaminated topsoil; and 3) P-amended, $\mathrm{Pb}$-contaminated topsoil. Each treatment was duplicated, and we used soil from 2 sites, yielding a total of 12 columns.

The columns were leached using a saturated, plug flow approach. The columns were initially saturated from below until each column had a $2 \mathrm{~cm}$ standing head of water. The columns were leached twice per week by opening the drain tube and maintaining the constant head with a Mariotte bottle. Leaching was continued until $1 \mathrm{~L}$ was collected at which time the drain tube was closed. The duration of the experiment was 8 weeks. We calculated that the pore (void) volume of each column was $1600 \mathrm{~mL}$. Over the course of the experiment, a total of $16 \mathrm{~L}$ or 10 pore volumes were collected.

Leachate Analysis Upon collection, the leachates were filtered through a $45 \mu \mathrm{m}$ filter. A $100 \mathrm{~mL}$ filtered aliquot was acidified with 5 drops of $\mathrm{HNO}_{3}$ and stored until analysis. Each sample was analyzed by graphite furnace-atomic absorption spectrometry. 


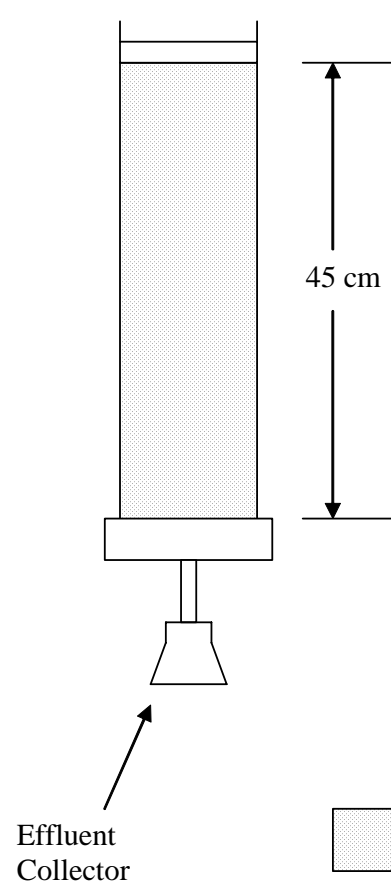

Control Soil (Non-Pb Contaminated)

Pb Contaminated Soil

Phosphorus Amended Pb Contaminated soil

Fig 2. Experimental design for the column study. The left column is the uncontaminated control; the middle column is $\mathrm{Pb}$-contaminated but untreated, and the right column is $\mathrm{Pb}$ contaminated soil with $P$ amendment.

\section{RESULTS}

\section{Site Selection}

We initially screened the sites based on age of the bridge and recent painting. We had a site visit for approximately 15 bridges, and eliminated all those that showed no signs of elevated $\mathrm{Pb}$ in the soil or with elevated $\mathrm{Pb}$ in a limited area. Two candidate bridges were found in Tippecanoe County, designated “I-65” (Fig. 3) and "Hwy 43” (Fig. 4). Our third site, "West Harrison” (Fig. 5), was abandoned after approximately 6 months due to flood waters eroding the Pbcontaminated sediments. Therefore, the project was completed using the two remaining sites. The general configuration of the bridge and contaminated areas are given in Figures 3 through 5. 


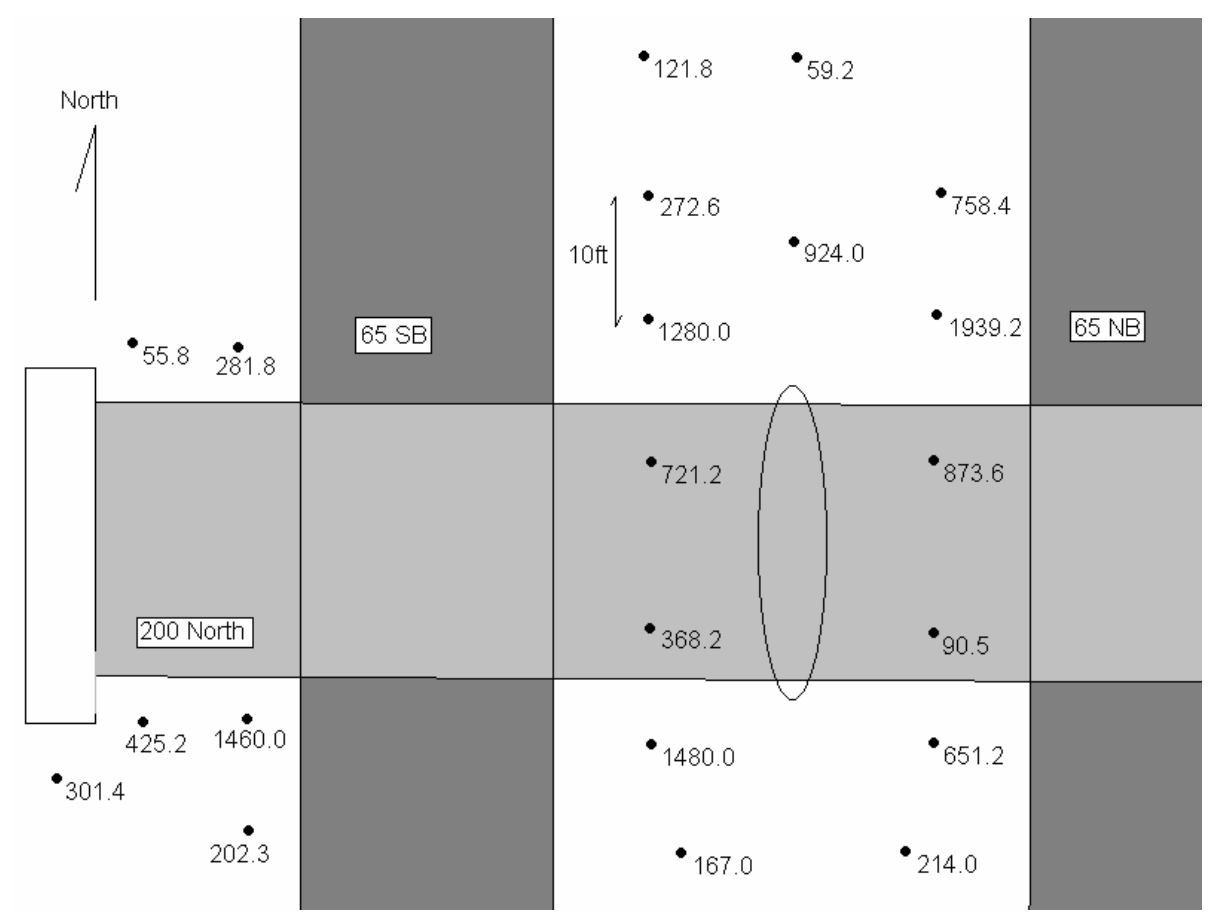

Figure 3. Field characterization of the $\mathrm{Pb}$ concentrations at the I-65 site (at $200 \mathrm{~N}$ in Tippecanoe County).

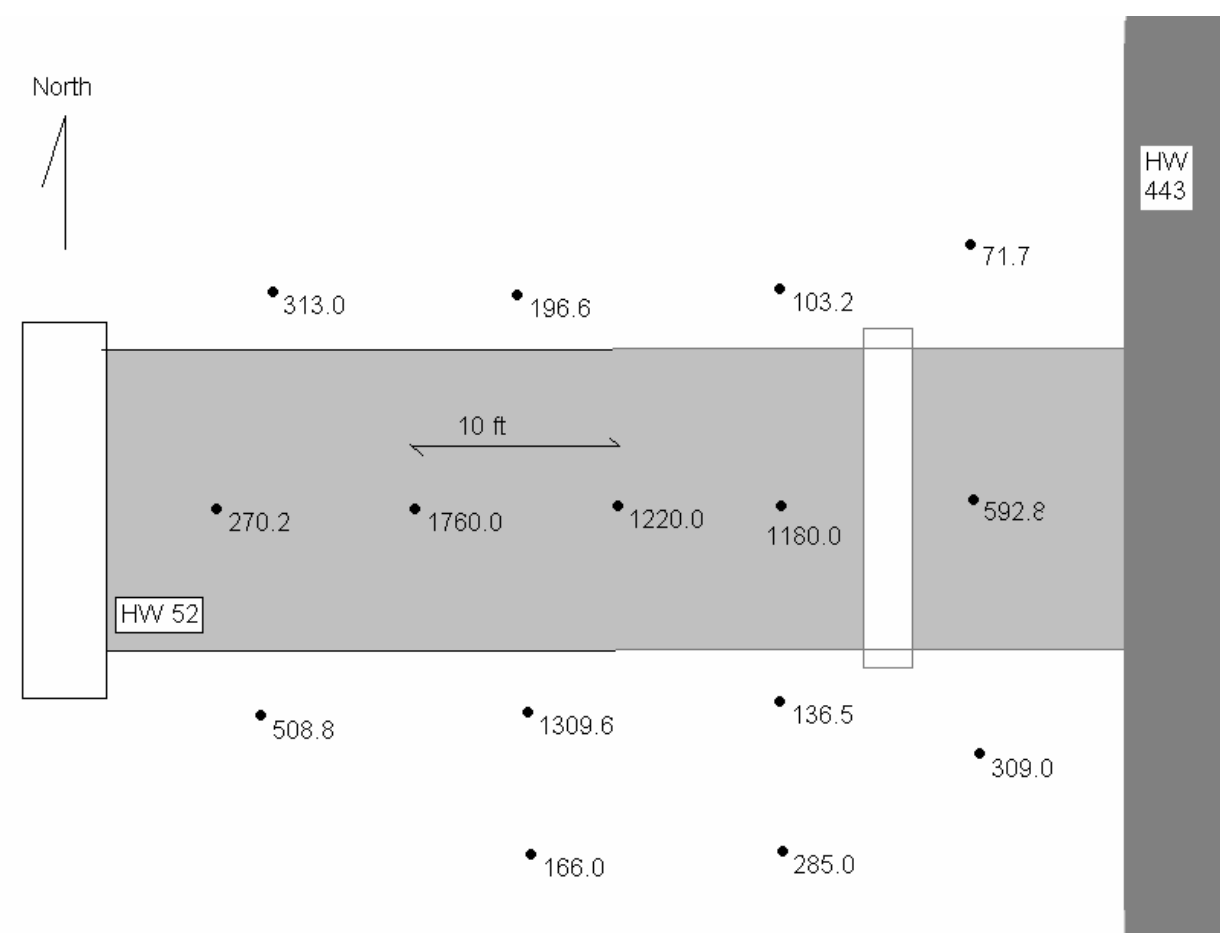

Fig. 4. Field characterization of the $\mathrm{Pb}$ concentrations at the Highway 43 site (under Highway 52 in Tippecanoe County). 


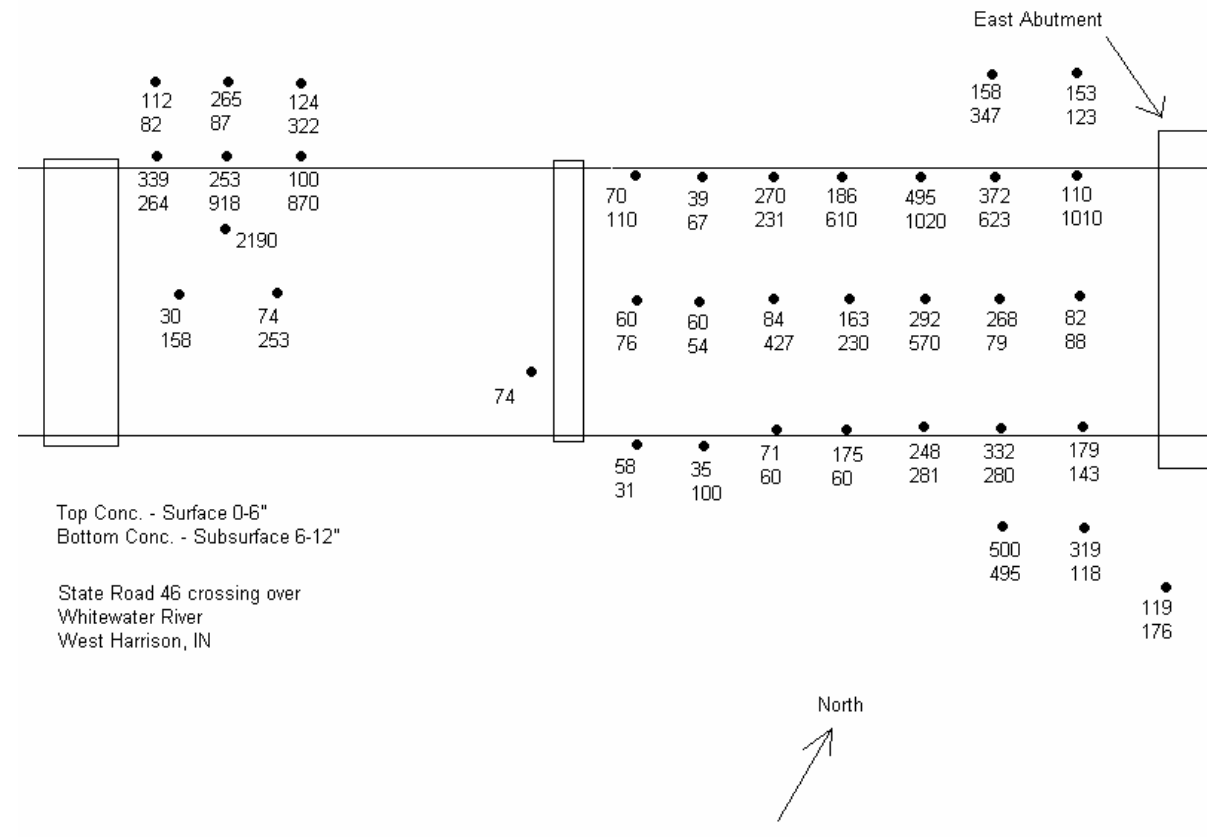

Figure. 5. Field characterization of the Pb concentrations at the West Harrison Bridge site.

\section{Field Study}

Sunflower Uptake of $\mathbf{P b}$ The sunflowers planted in both the median of I-65 and under the Highway 52 bridge on Highway 43 were subject to the whims of the weather. We had no means of irrigating these sites, and the Hwy 43 site was heavily shaded from the overlying bridge. Although the sunflowers germinated and emerged at both sites, the unfavorable conditions at the Hwy 43 site resulted in 100\% mortality of the plants. The plants at the I-65 grew well throughout the experiment. The plants were harvested after a full season of growth, dried, and analyzed for $\mathrm{Pb}$. The mean $\mathrm{Pb}$ concentration for the plants was $33 \mathrm{mg} / \mathrm{kg}$. This rate of uptake is quite typical for plants growing in soil and would be unsuitable for phytoremediation efforts.

\section{Immobilization of $\mathbf{P b}$ by Phosphate}

Soluble phosphate was added to the soil at a mole ratio of 3:1 $\mathrm{P}: \mathrm{Pb}$ to ensure that the insoluble lead phosphate, chloropyromorphite, will form in place. The granular phosphate fertilizer was raked into the soil. After nearly one year, the soils were sampled and analyzed for bioaccessible $\mathrm{Pb}$ using the physiologically based extraction test (PBET). PBET concentrations in phosphorus treated soil and untreated soil were compared to PBET concentrations prior to treatment (Fig. 6). The concentrations were converted to a percentage of that prior to treatment:

$$
\% \text { PBET extractable }=\left(\frac{P B E T_{\text {initial }}-P B E T_{\text {final }}}{P B E T_{\text {initial }}}\right) * 100 \%
$$




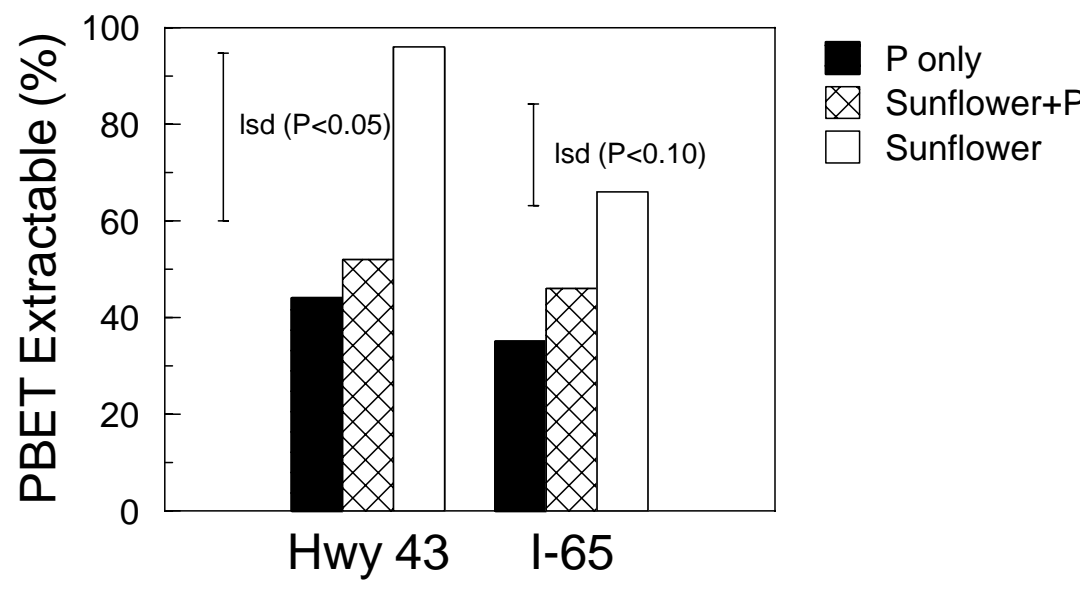

Figure 6. PBET-extractable $\mathrm{Pb}$ in the contaminated soils amended with soluble phosphate. PBET concentrations are reported as a percentage of the original PBET-Pb in the unamended soils immediately prior to treatment. The error bars represent the mean separation at the indicated confidence level. For I-65, the differences were not significant at $\mathbf{P}<\mathbf{0 . 0 5}$.

The mean \%PBET-Pb in the sunflower plots without additional $\mathrm{P}$ was higher than those plots with added $\mathrm{P}$ for both sites. The differences between P-treated and P-untreated were significant at the $\mathrm{P}<0.05$ for the Hwy 43 site and at the $\mathrm{P}<0.10$ level for the I-65 site. The reductions in bioaccessibility are consistent with similar, published laboratory studies (Hettiarachchi et al., 2000) and suggest that this method is a feasible remediation technique for mildly contaminated field soils.

The I-65 soils were less responsive to $\mathrm{P}$ additions probably because of the relatively smaller $\mathrm{Pb}$ concentrations. With lower initial $\mathrm{Pb}$ concentrations, the untreated soils experienced notable decreases in PBET-Pb concentrations due to simple mixing of the soils. Without question the $\mathrm{Pb}$ contamination at the I-65 site was superficial as a result of Pb-bearing paint residue being deposited from above. Any surface disturbance, such as mixing in fertilizer $\mathrm{P}$ with a rake, has the potential to dilute the PBET-Pb through a simple process of mixing with uncontaminated soil. Thus, the impact of $\mathrm{P}$ additions was diminished.

\section{Column study}

The objective of this study was to determine if the $\mathrm{Pb}$ in the contaminated soils from the bridge sites had the possibility of being mobile and if the addition of soluble $\mathrm{P}$ would reduce mobility. The design of the columns is shown in Figure 2. Contaminated and uncontaminated soils were obtained from the Hwy 43 and I-65 sites. Treatments were uncontaminated soil, contaminated + $\mathrm{P}$, and contaminated soil without P. Each treatment was run in duplicate for a total of 12 columns.

The columns were leached for nearly 60 days with 10 pore volumes of leaching, and the concentrations of $\mathrm{Pb}$ in the leachates were determined in twelve sets of samples. Relatively high 
concentrations ( 1 to $3 \mu \mathrm{g} / \mathrm{L}$ ) were observed in the Hwy 43 samples in the first leachates obtained (Fig. 7). All other samples were below $1 \mu \mathrm{g} / \mathrm{L}$. For the I-65 samples, the concentrations were similar to the Hwy 43 samples but with lower concentrations in the first leachates; a few samples had concentrations greater than $1 \mu \mathrm{g} / \mathrm{L}$. From these graphs, it is not clear whether the addition of $\mathrm{P}$ had a significant impact on Pb leaching.

I-65

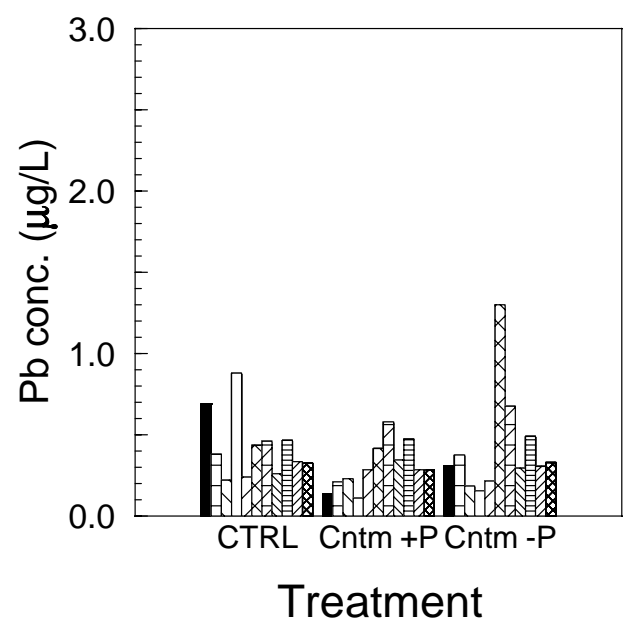

Hwy 43

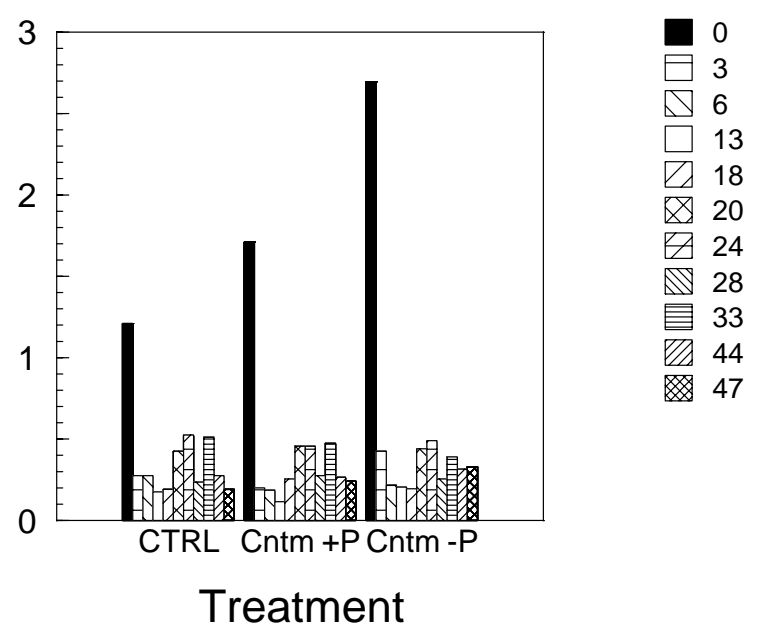

Figure 7. Concentrations of $\mathrm{Pb}$ in leachates in the column study. The bars represent concentrations at the given number of days of leaching.

An alternative way of viewing the data is to calculate the total mass of $\mathrm{Pb}$ leached. This is obtained by multiplying the concentration in the samples collected by the volume of the sample. The results are given in the table below:

Table 2. Mass of $\mathrm{Pb}$ leached in each column. For each site, mean values followed by the same letter are not significantly different. Reported values are means \pm standard deviation (ns = not significant).

\begin{tabular}{|c|c|c|}
\hline Soil/Treatment & I-65 & Highway 43 \\
\hline & \multicolumn{2}{|c|}{------------------------------ Hg --------------------------- } \\
\hline Uncontaminated & $8.084 \pm 0.24 b$ & $6.74 \pm 0.16(\mathrm{~ns})$ \\
\hline Pb-contaminated/untreated & $10.08 \pm 0.22 \mathrm{a}$ & $7.34 \pm 0.12$ (ns) \\
\hline $\mathrm{Pb}$-contaminated/P-treated & $8.04 \pm 0.16 \mathrm{~b}$ & $6.88 \pm 0.26(\mathrm{~ns})$ \\
\hline
\end{tabular}

These data show the trend that the contaminated soil had the highest mass of leached $\mathrm{Pb}$, and that the addition of $\mathrm{P}$ to the contaminated soil reduced the mass of $\mathrm{Pb}$ to that of the uncontaminated soils. These trends were significant in the I-65 soil but not in the soil from Highway 43. 


\section{COST COMPARISONS}

Traditional treatment of $\mathrm{Pb}$-contaminated soil is to excavate the contaminated material and take it to a hazardous waste landfill. Other approaches include soil solidification (adding substances to the soil to make an impermeable block) and soil extraction, washing the soil with solvents to remove metals. The costs of these approaches have been summarized and several occasions, and the numbers in Table 3 are representative of those published elsewhere.

\begin{tabular}{lccl}
\hline Type of Treatment & Cost & Time Required & $\begin{array}{l}\text { Additional } \\
\text { Factors/Expense }\end{array}$ \\
\hline Fixation & $\$ / \mathrm{m}^{2}$ & months & \\
Landfilling & $90-200$ & $6-9$ & Transport/excavation \\
Soil extraction & $100-400$ & $6-9$ & Long-term monitoring \\
& $250-500$ & $8-12$ & $5,000 \mathrm{~m}^{3}$ minimum \\
Phytoremediation & $15-40$ & $18-60$ & Chemical recycle \\
& & & Time/land commitment \\
\hline
\end{tabular}

\section{CONCLUSIONS}

The four objectives of this proposal were met during the execution of the field and laboratory phases of this project. From our observations, we conclude the following:

1. The extent of $\mathrm{Pb}$ contamination from paint removal on highway bridges is not extensive. Of the 15 bridges we visited, only 3 had soil- $\mathrm{Pb}$ concentrations that were high enough and expansive enough to merit study. It seems that the current abatement procedures are generally effective.

2. Phytoremediation for $\mathrm{Pb}$ is challenging due to the nature of the chemistry of $\mathrm{Pb}$, and our attempts at using sunflower in this context were unsuccessful.

3. The addition of soluble phosphate to these soils was an effective approach to immobilizing $\mathrm{Pb}$ and reducing its bioaccessibility. For both field sites, decreases in bioaccessibility were obvious as shown by the PBET method.

4. The cost of immobilization is far less than traditional decontamination approaches. Due to the simplicity of the approach and the general lack of severity of $\mathrm{Pb}$ contamination near highway bridges, we strongly recommend adding phosphate to $\mathrm{Pb}$-contaminated soils when the problem arises. 


\section{References}

Baker, J.M., R.D. Reeves, and A.S.M. Hajar. 1994. Heavy metal acumulaiton and tolerance in British populations of the metallophyte Thlaspi caerulescens. New Phytol. 127:61-68.

Bruell, R., N.P. Nikolaidis, and R.P. Long. 1999. Evaluation of remedial alternatives of lead from shooting range soil. Environ. Engg. Sci. 16:403-413.

Chen, Xiao Bing, J.V. Wright, J.L. Conca, and L.M. Peurrung. 1997. Evaluation of heavy metal remediation using mineral apatite. Water, Air, and Soil Pollution. 98:57-78.

Cunningham S.D., J.R. Shann, D.E. Crowley, W. Berti, and J. Huang. 1997. Phytoremediation of contaminated water and soil. ACS Symp. Series 664: 2-17.

Grohse, P.M., K.K. Luk, W.F. Gutknecht, S.L. Harper, M.E. Beard, B.S. Lim, and J.J. Breen. 1992. Development of a field-test method for the determination of lead in paint, and paint contaminated dust and soil. Abst. Pap. Amer. Chem. Soc. 204:52.

Hettiarachchi GM, Pierzynski GM, Ransom MD. 2000. In situ stabilization of soil lead using phosphorus and manganese oxide. Environ. Sci. Tech. 34:4614-4619.

Indiana Department of Environmental Management. 1996. VRP Lead Policy. OER-0005-NPD.

Kimmel, T.A. 1988. Development, evaluation and use of the Toxicity Characteristic Leaching Procedure (TCLP). In Lichtenbert, J.J., J.A. Winter, C.I. Weber, and L. Fradkin (eds), Chemical and Biological Characerization of Sludges, Sediments, Dredge Spoil, and Drilling Muds. ASTM STP 976Amer. Soc. Testing Materials, Philadephia, PA. Pp 129140.

Rodriguez, R.R., Basta, N.T., Casteel, S.W., and Pace, L.W. 1999. An in vitro gastrointestinal method to estimate bioavailable arsenic in contaminated soils and solid media. Environ. Sci. Tech. 33:642-649.

Ruby, M.V., Davis, A., Schoof, R., Eberle, S., and Sellstone, C.M. 1996. Estimation of lead and arsenic bioavailability using a physiologically based extraction test. Environ. Sci. Tech. 30:422-430.

Sposito, G., L.J. Lund, and A.C. Chang. 1982. Trace metal chemistry in arid-zone field soils amended with sewage sludge: I. Fractionation of $\mathrm{Ni}, \mathrm{Cu}, \mathrm{Zn}, \mathrm{Cd}$, and $\mathrm{Pb}$ in solid phases. Soil Sci. Soc. Am. J. 46:260-264.

Steel Structures Painting Council. 1991. Lead paint removal : meeting the challenge proceedings of the 4th annual conference, lead paint removal from industrial structures. -- Pittsburgh, PA Steel Structures Painting Council. Report no. SSPC 91-05.

Tillison, D. 1995. Phytoremediation: from lab to field. HazTech Transfer, October 1995. Great Plains/Rocky Mountain Hazardous Substance Research Center. pg. 1-2. Kans. St. Univ.

U.S. Environmental Protection Agency. 2001. Lead; Identification of dangerous level of lead. 400 CFR-745, [OPPTS-62156H; FRL-6763-5], In Federal Register, Friday January 5, 2001. Washington D.C. http://www.epa.gov/opptintr/lead/index.html

Wang, M.K. G.K. Chuah, K.P. Ang, and L.L. Koh. 1986. Interactive effects of lead, cadmium and copper combinations in the uptake of metals and grwoth of Brassica chinensis. Environ. Experimental Bot. 26:331-339.

Wu, J., F.C. Hsu, and S.D. Cunningham. 1999. Chelate assisted Pb phytoextraction: $\mathrm{Pb}$ availability, uptake, and translocation constraints. Environ. Sci. Techn. 33:1898-1904.

Zhang, P., and J.A. Ryan. 1998. In vitro soil Pb solubility in the presence of hydroxyapatite. Environ. Sci. Technol. 32:2763-2768. 


\section{APPENDIX: LEAD ANALYSES FOR THE FIELD SITES}

Appendix 1. Lead analyses of samples from West Harrison Bridge.

West Harrison - Indiana State Highway 46 Bridge

\begin{tabular}{|c|c|c|c|}
\hline Sample Location & Depth & $\begin{array}{c}\text { Lab Analysis } \\
\text { (mg Pb/kg) }\end{array}$ & $\begin{array}{l}\text { Field Analy. } \\
(\mathrm{mg} \mathrm{Pb} / \mathrm{kg})\end{array}$ \\
\hline$A$ & $0-6^{\prime \prime}$ & 1,200 * & 972 \\
\hline B & $0-6 "$ & 140 * & 118.6 \\
\hline $\mathrm{B}$ & 6-10" & $11^{*}$ & 176.4 \\
\hline C & $0-6 "$ & 820 * & 74.1 \\
\hline $\mathrm{D}$ & $0-6 "$ & $170^{*}$ & 2188.8 \\
\hline 1 & $0-6 "$ & 153.8 & \\
\hline 1 & 6-10" & 123.5 & \\
\hline 2 & $0-6 "$ & 109.9 & \\
\hline 2 & 6-10" & 1009.6 & \\
\hline 3 & $0-6 "$ & 81.6 & \\
\hline 3 & 6-10" & 87.9 & \\
\hline 4 & $0-6 "$ & 179.0 & \\
\hline 4 & 6-10" & 143.8 & \\
\hline 5 & $0-6 "$ & 319.8 & \\
\hline 5 & 6-10" & 118.3 & \\
\hline 6 & $0-6 "$ & 158.9 & \\
\hline 6 & 6-10" & 347.4 & \\
\hline 7 & $0-6 "$ & 372.4 & \\
\hline 7 & 6-10" & 622.8 & \\
\hline 8 & $0-6 "$ & 268.2 & \\
\hline 8 & 6-10" & 78.9 & \\
\hline 9 & $0-6 "$ & 332.4 & \\
\hline 9 & 6-10" & 277.6 & \\
\hline 10 & $0-6 "$ & 500.8 & \\
\hline 10 & 6-10" & 494.8 & \\
\hline 11 & $0-6 "$ & 1020.0 & \\
\hline 11 & 6-10" & 111.8 & \\
\hline 12 & $0-6 "$ & 292.0 & \\
\hline 12 & 6-10" & 570.8 & \\
\hline 13 & $0-6 "$ & 248.4 & \\
\hline 13 & 6-10" & 281.2 & \\
\hline 14 & $0-6 "$ & 186.2 & \\
\hline 14 & 6-10" & 610.0 & \\
\hline 15 & $0-6^{\prime \prime}$ & 162.8 & \\
\hline 15 & 6-10" & 229.4 & \\
\hline
\end{tabular}




\begin{tabular}{|c|c|c|}
\hline 17 & $0-6 "$ & 269.2 \\
\hline 17 & 6-10" & 230.6 \\
\hline 18 & $0-6 "$ & 83.9 \\
\hline 18 & 6-10" & 427.2 \\
\hline 19 & $0-6 "$ & 71.2 \\
\hline 19 & 6-10" & 59.8 \\
\hline 20 & $0-6 "$ & 70.6 \\
\hline 20 & 6-10" & 110.9 \\
\hline 21 & $0-6 "$ & 60.2 \\
\hline 21 & 6-10" & 76.4 \\
\hline 22 & $0-6 "$ & 57.7 \\
\hline 22 & 6-10" & 30.7 \\
\hline 23 & $0-6 "$ & 38.7 \\
\hline 23 & 6-10" & 66.7 \\
\hline 24 & $0-6 "$ & 60.0 \\
\hline 24 & 6-10" & 53.6 \\
\hline 25 & $0-6 "$ & 68.6 \\
\hline 25 & 6-10" & 34.5 \\
\hline 26 & $0-6^{\prime \prime}$ & 100.8 \\
\hline 26 & 6-10" & 870.4 \\
\hline 27 & $0-6 "$ & 124.5 \\
\hline 27 & 6-10" & 322.0 \\
\hline 28 & $0-6 "$ & 87.5 \\
\hline 28 & 6-10" & 73.7 \\
\hline 29 & $0-6 "$ & 253.0 \\
\hline 29 & 6-10" & 917.6 \\
\hline 30 & $0-6 "$ & 264.8 \\
\hline 30 & 6-10" & 86.9 \\
\hline 31 & $0-6 "$ & 30.3 \\
\hline 31 & 6-10" & 157.9 \\
\hline 32 & $0-6 "$ & 338.8 \\
\hline 32 & 6-10" & 263.6 \\
\hline 33 & $0-6 "$ & 112.5 \\
\hline 33 & 6-10" & 82.1 \\
\hline
\end{tabular}

* From Capital Environmental Enterprises, Inc. Location approximate. 
West Lafayette - Sagamore \& Northwestern Bridge

\begin{tabular}{|c|c|c|c|}
\hline Sample Location & Depth (in) & \begin{tabular}{|c|} 
Field Analysis \\
$\mathrm{Pb}$ Conc. (ppm)
\end{tabular} & $\begin{array}{l}\text { Lab Analysis } \\
\mathrm{Pb} \text { Conc. (ppm) }\end{array}$ \\
\hline 1 & $0-2^{\prime \prime}$ & 1819.2 & 763.6 \\
\hline 1 & $2-4 "$ & & 454.0 \\
\hline 2 & $0-2 "$ & 844.8 & 265.4 \\
\hline 2 & 2-4" & & 82.0 \\
\hline 3 & $0-2^{\prime \prime}$ & 387.4 & 147.9 \\
\hline 3 & 2-4" & & 94.4 \\
\hline 4 & $0-2 "$ & 139.4 & 96.5 \\
\hline 4 & 2-4" & & 67.5 \\
\hline 5 & $0-2 "$ & 101.0 & 96.8 \\
\hline 5 & $2-4 "$ & & 54.7 \\
\hline 6 & $0-2 "$ & 116.1 & 57.9 \\
\hline 6 & $2-4 "$ & & 63.2 \\
\hline 7 & $0-2 "$ & 72.2 & 66.6 \\
\hline 7 & $2-4 "$ & & 32.2 \\
\hline 8 & $0-2^{\prime \prime}$ & 61.7 & 78.1 \\
\hline 8 & $2-4 "$ & & 61.4 \\
\hline 9 & $0-2^{\prime \prime}$ & 60.9 & 72.3 \\
\hline 9 & $2-4 "$ & & 42.6 \\
\hline 10 & $0-2^{\prime \prime}$ & 24.6 & 56.7 \\
\hline 10 & $2-4 "$ & & 38.5 \\
\hline 11 & $0-2^{\prime \prime}$ & 379.4 & 217.4 \\
\hline 11 & 2-4" & & 229.4 \\
\hline 12 & $0-2 "$ & 350.2 & 128.7 \\
\hline 12 & 2-4" & & 133.9 \\
\hline 13 & $0-2^{\prime \prime}$ & 125.1 & 110.4 \\
\hline 13 & 2-4" & & 83.7 \\
\hline 14 & $0-2^{\prime \prime}$ & 135.4 & 301.2 \\
\hline 14 & 2-4" & & 212.6 \\
\hline 15 & $0-2 "$ & 320.2 & 274.6 \\
\hline 15 & 2-4" & & 238.8 \\
\hline 16 & $0-2 "$ & 119.5 & 124.0 \\
\hline 16 & 2-4" & & 56.1 \\
\hline 17 & $0-2^{\prime \prime}$ & 159.2 & 119.5 \\
\hline 17 & 2-4" & & 66.7 \\
\hline 18 & $0-2 "$ & 234.6 & 170.4 \\
\hline 18 & 2-4" & & 146.7 \\
\hline 19 & $0-2 "$ & 45.0 & 59.0 \\
\hline 19 & 2-4" & & 45.3 \\
\hline
\end{tabular}




\begin{tabular}{|c|c|c|c|}
\hline 20 & $0-2^{\prime \prime}$ & 72.0 & 77.4 \\
\hline 20 & $2-4^{\prime \prime}$ & & 56.8 \\
\hline 21 & $0-2^{\prime \prime}$ & 46.7 & 71.4 \\
\hline 21 & 2-4" & & 56.5 \\
\hline 22 & $0-2^{\prime \prime}$ & 191.5 & 107.4 \\
\hline 22 & $2-4^{\prime \prime}$ & & 141.5 \\
\hline 23 & $0-2^{\prime \prime}$ & 123.2 & 105.3 \\
\hline 23 & $2-4^{\prime \prime}$ & & 112.0 \\
\hline 24 & $0-2^{\prime \prime}$ & 40.7 & 62.1 \\
\hline 24 & 2-4" & & 56.2 \\
\hline 25 & $0-2^{\prime \prime}$ & 199.2 & 114.4 \\
\hline 25 & 2-4" & & 75.0 \\
\hline 26 & $0-2^{\prime \prime}$ & 82.2 & 60.5 \\
\hline 26 & $2-4^{\prime \prime}$ & & 44.7 \\
\hline 27 & $0-2^{\prime \prime}$ & 92.1 & 101.8 \\
\hline 27 & $2-4^{\prime \prime}$ & & 49.8 \\
\hline 28 & $0-2^{\prime \prime}$ & 69.9 & 52.7 \\
\hline 28 & $2-4^{\prime \prime}$ & & 49.6 \\
\hline 29 & $0-2^{\prime \prime}$ & 45.5 & 47.1 \\
\hline 29 & 2-4" & & 52.3 \\
\hline 30 & $0-2^{\prime \prime}$ & 94.1 & 83.8 \\
\hline 30 & $2-4^{\prime \prime}$ & & 38.9 \\
\hline 31 & $0-2^{\prime \prime}$ & 49.6 & 58.7 \\
\hline 31 & 2-4" & & 43.0 \\
\hline 32 & $0-2^{\prime \prime}$ & 79.8 & 83.8 \\
\hline 32 & 2-4" & & 66.8 \\
\hline 33 & $0-2^{\prime \prime}$ & 80.0 & 126.3 \\
\hline 33 & $2-4^{\prime \prime}$ & & 69.6 \\
\hline 34 & $0-2^{\prime \prime}$ & 53.8 & 60.5 \\
\hline 34 & 2-4" & & 49.0 \\
\hline 35 & $0-2^{\prime \prime}$ & 98.2 & 92.1 \\
\hline 35 & $2-4^{\prime \prime}$ & & 51.5 \\
\hline 36 & $0-2^{\prime \prime}$ & 41.6 & 48.6 \\
\hline 36 & 2-4" & & 46.0 \\
\hline 37 & $0-2^{\prime \prime}$ & 75.9 & 59.7 \\
\hline 37 & 2-4" & & 64.5 \\
\hline 38 & $0-2^{\prime \prime}$ & 34.1 & 39.9 \\
\hline 38 & 2-4" & & 29.7 \\
\hline 39 & $0-2^{\prime \prime}$ & 81.9 & 44.4 \\
\hline 39 & 2-4" & & 42.8 \\
\hline 40 & $0-2^{\prime \prime}$ & 29.5 & 41.1 \\
\hline 40 & $2-4^{\prime \prime}$ & & 33.3 \\
\hline
\end{tabular}


I-65 Total Pb Analyses.

\begin{tabular}{|c|c|c|}
\hline Sample I.D. & Depth & $\mathrm{Pb}$ (mg/kg) \\
\hline 1 & $0-2 "$ & 122 \\
\hline 1 & $2-4 "$ & 58 \\
\hline 2 & $0-2 "$ & 59 \\
\hline 2 & $2-4 "$ & 46 \\
\hline 3 & $0-2 "$ & 273 \\
\hline 3 & $2-4 "$ & 104 \\
\hline 4 & $0-2$ & 758 \\
\hline 4 & $2-4 "$ & 65 \\
\hline 5 & $0-2 "$ & 924 \\
\hline 5 & $2-4 "$ & 46 \\
\hline 6 & $0-2 "$ & 56 \\
\hline 6 & $2-4 "$ & 57 \\
\hline 7 & $0-2 "$ & 282 \\
\hline 7 & $2-4 "$ & 122 \\
\hline 8 & $0-2 "$ & 1280 \\
\hline 8 & $2-4$ & 136 \\
\hline 9 & $0-2 "$ & 1940 \\
\hline 9 & $2-4 "$ & 67 \\
\hline 10 & $0-2 "$ & 721 \\
\hline 10 & $2-4 "$ & 100 \\
\hline 11 & $0-2 "$ & 874 \\
\hline 11 & $2-4 "$ & 45 \\
\hline 12 & $0-2 "$ & 368 \\
\hline 12 & $2-4 "$ & 78 \\
\hline 13 & $0-2 "$ & 91 \\
\hline 13 & $2-4 "$ & 77 \\
\hline 14 & $0-2 "$ & 425 \\
\hline 14 & $2-4 "$ & 57 \\
\hline 15 & $0-2 "$ & 1460 \\
\hline 15 & $2-4 "$ & 73 \\
\hline 16 & $0-2 "$ & 651 \\
\hline 16 & $2-4 "$ & 203 \\
\hline 17 & $0-2 "$ & 1480 \\
\hline 17 & $2-4 "$ & 122 \\
\hline 18 & $0-2 "$ & 301 \\
\hline 18 & $2-4 "$ & 85 \\
\hline 19 & $0-2 "$ & 202 \\
\hline 19 & $2-4 "$ & 80 \\
\hline 20 & $0-2 "$ & 167 \\
\hline 20 & $2-4 "$ & 39 \\
\hline 21 & $0-2 "$ & 214 \\
\hline 21 & $2-4 "$ & 66 \\
\hline
\end{tabular}


Highway 43 Analyses.

\begin{tabular}{|c|c|c|}
\hline Sample I.D. & Depth & $\mathrm{Pb}$ (mg/kg) \\
\hline 1 & $0-2 "$ & 313 \\
\hline 1 & $2-4 "$ & 79 \\
\hline 2 & $0-2 "$ & 197 \\
\hline 2 & 2-4" & 61 \\
\hline 3 & $0-2 "$ & 103 \\
\hline 3 & 2-4" & 58 \\
\hline 4 & $0-2 "$ & 72 \\
\hline 4 & 2-4" & 38 \\
\hline 5 & $0-2 "$ & 270 \\
\hline 5 & $2-4 "$ & 170 \\
\hline 6 & $0-2 "$ & 1760 \\
\hline 6 & 2-4" & 301 \\
\hline 7 & $0-2 "$ & 1220 \\
\hline 7 & $2-4 "$ & 266 \\
\hline 8 & $0-2 "$ & 1180 \\
\hline 8 & $2-4 "$ & 113 \\
\hline 9 & $0-2 "$ & 592 \\
\hline 9 & $2-4 "$ & 143 \\
\hline 10 & $0-2 "$ & 508 \\
\hline 10 & $2-4 "$ & 86 \\
\hline 11 & $0-2 "$ & 1310 \\
\hline 11 & $2-4 "$ & 263 \\
\hline 12 & $0-2 "$ & 136 \\
\hline 12 & $2-4 "$ & 41 \\
\hline 13 & $0-2 "$ & 309 \\
\hline 13 & $2-4 "$ & 47 \\
\hline 14 & $0-2 "$ & 166 \\
\hline 14 & $2-4 "$ & 75 \\
\hline 15 & $0-2 "$ & 285 \\
\hline 15 & $2-4 "$ & 171 \\
\hline
\end{tabular}




\section{References}

Baker, J.M., R.D. Reeves, and A.S.M. Hajar. 1994. Heavy metal acumulaiton and tolerance in British populations of the metallophyte Thlaspi caerulescens. New Phytol. 127:61-68.

Bruell, R., N.P. Nikolaidis, and R.P. Long. 1999. Evaluation of remedial alternatives of lead from shooting range soil. Environ. Engg. Sci. 16:403-413.

Chen, Xiao Bing, J.V. Wright, J.L. Conca, and L.M. Peurrung. 1997. Evaluation of heavy metal remediation using mineral apatite. Water, Air, and Soil Pollution. 98:57-78.

Cunningham S.D., J.R. Shann, D.E. Crowley, W. Berti, and J. Huang. 1997. Phytoremediation of contaminated water and soil. ACS Symp. Series 664: 2-17.

Grohse, P.M., K.K. Luk, W.F. Gutknecht, S.L. Harper, M.E. Beard, B.S. Lim, and J.J. Breen. 1992. Development of a field-test method for the determination of lead in paint, and paint contaminated dust and soil. Abst. Pap. Amer. Chem. Soc. 204:52.

Hettiarachchi GM, Pierzynski GM, Ransom MD. 2000. In situ stabilization of soil lead using phosphorus and manganese oxide. Environ. Sci. Tech. 34:4614-4619.

Indiana Department of Environmental Management. 1996. VRP Lead Policy. OER-0005-NPD.

Kimmel, T.A. 1988. Development, evaluation and use of the Toxicity Characteristic Leaching Procedure (TCLP). In Lichtenbert, J.J., J.A. Winter, C.I. Weber, and L. Fradkin (eds), Chemical and Biological Characerization of Sludges, Sediments, Dredge Spoil, and Drilling Muds. ASTM STP 976Amer. Soc. Testing Materials, Philadephia, PA. Pp 129140.

Rodriguez, R.R., Basta, N.T., Casteel, S.W., and Pace, L.W. 1999. An in vitro gastrointestinal method to estimate bioavailable arsenic in contaminated soils and solid media. Environ. Sci. Tech. 33:642-649.

Ruby, M.V., Davis, A., Schoof, R., Eberle, S., and Sellstone, C.M. 1996. Estimation of lead and arsenic bioavailability using a physiologically based extraction test. Environ. Sci. Tech. 30:422-430.

Sposito, G., L.J. Lund, and A.C. Chang. 1982. Trace metal chemistry in arid-zone field soils amended with sewage sludge: I. Fractionation of $\mathrm{Ni}, \mathrm{Cu}, \mathrm{Zn}, \mathrm{Cd}$, and $\mathrm{Pb}$ in solid phases. Soil Sci. Soc. Am. J. 46:260-264.

Steel Structures Painting Council. 1991. Lead paint removal : meeting the challenge proceedings of the 4th annual conference, lead paint removal from industrial structures. -- Pittsburgh, PA Steel Structures Painting Council. Report no. SSPC 91-05.

Tillison, D. 1995. Phytoremediation: from lab to field. HazTech Transfer, October 1995. Great Plains/Rocky Mountain Hazardous Substance Research Center. pg. 1-2. Kans. St. Univ.

U.S. Environmental Protection Agency. 2001. Lead; Identification of dangerous level of lead. 400 CFR-745, [OPPTS-62156H; FRL-6763-5], In Federal Register, Friday January 5, 2001. Washington D.C. http://www.epa.gov/opptintr/lead/index.html

Wang, M.K. G.K. Chuah, K.P. Ang, and L.L. Koh. 1986. Interactive effects of lead, cadmium and copper combinations in the uptake of metals and grwoth of Brassica chinensis. Environ. Experimental Bot. 26:331-339.

Wu, J., F.C. Hsu, and S.D. Cunningham. 1999. Chelate assisted Pb phytoextraction: $\mathrm{Pb}$ availability, uptake, and translocation constraints. Environ. Sci. Techn. 33:1898-1904.

Zhang, P., and J.A. Ryan. 1998. In vitro soil Pb solubility in the presence of hydroxyapatite. Environ. Sci. Technol. 32:2763-2768. 


\section{APPENDIX: LEAD ANALYSES FOR THE FIELD SITES}

Appendix 1. Lead analyses of samples from West Harrison Bridge.

West Harrison - Indiana State Highway 46 Bridge

\begin{tabular}{|c|c|c|c|}
\hline Sample Location & Depth & $\begin{array}{c}\text { Lab Analysis } \\
\text { (mg Pb/kg) }\end{array}$ & $\begin{array}{l}\text { Field Analy. } \\
(\mathrm{mg} \mathrm{Pb} / \mathrm{kg})\end{array}$ \\
\hline$A$ & $0-6^{\prime \prime}$ & 1,200 * & 972 \\
\hline B & $0-6 "$ & 140 * & 118.6 \\
\hline $\mathrm{B}$ & 6-10" & $11^{*}$ & 176.4 \\
\hline C & $0-6 "$ & 820 * & 74.1 \\
\hline $\mathrm{D}$ & $0-6 "$ & $170^{*}$ & 2188.8 \\
\hline 1 & $0-6 "$ & 153.8 & \\
\hline 1 & 6-10" & 123.5 & \\
\hline 2 & $0-6 "$ & 109.9 & \\
\hline 2 & 6-10" & 1009.6 & \\
\hline 3 & $0-6 "$ & 81.6 & \\
\hline 3 & 6-10" & 87.9 & \\
\hline 4 & $0-6 "$ & 179.0 & \\
\hline 4 & 6-10" & 143.8 & \\
\hline 5 & $0-6 "$ & 319.8 & \\
\hline 5 & 6-10" & 118.3 & \\
\hline 6 & $0-6 "$ & 158.9 & \\
\hline 6 & 6-10" & 347.4 & \\
\hline 7 & $0-6 "$ & 372.4 & \\
\hline 7 & 6-10" & 622.8 & \\
\hline 8 & $0-6 "$ & 268.2 & \\
\hline 8 & 6-10" & 78.9 & \\
\hline 9 & $0-6 "$ & 332.4 & \\
\hline 9 & 6-10" & 277.6 & \\
\hline 10 & $0-6 "$ & 500.8 & \\
\hline 10 & 6-10" & 494.8 & \\
\hline 11 & $0-6 "$ & 1020.0 & \\
\hline 11 & 6-10" & 111.8 & \\
\hline 12 & $0-6 "$ & 292.0 & \\
\hline 12 & 6-10" & 570.8 & \\
\hline 13 & $0-6 "$ & 248.4 & \\
\hline 13 & 6-10" & 281.2 & \\
\hline 14 & $0-6 "$ & 186.2 & \\
\hline 14 & 6-10" & 610.0 & \\
\hline 15 & $0-6^{\prime \prime}$ & 162.8 & \\
\hline 15 & 6-10" & 229.4 & \\
\hline
\end{tabular}




\begin{tabular}{|c|c|c|}
\hline 17 & $0-6 "$ & 269.2 \\
\hline 17 & 6-10" & 230.6 \\
\hline 18 & $0-6 "$ & 83.9 \\
\hline 18 & 6-10" & 427.2 \\
\hline 19 & $0-6 "$ & 71.2 \\
\hline 19 & 6-10" & 59.8 \\
\hline 20 & $0-6 "$ & 70.6 \\
\hline 20 & 6-10" & 110.9 \\
\hline 21 & $0-6 "$ & 60.2 \\
\hline 21 & 6-10" & 76.4 \\
\hline 22 & $0-6 "$ & 57.7 \\
\hline 22 & 6-10" & 30.7 \\
\hline 23 & $0-6 "$ & 38.7 \\
\hline 23 & 6-10" & 66.7 \\
\hline 24 & $0-6 "$ & 60.0 \\
\hline 24 & 6-10" & 53.6 \\
\hline 25 & $0-6 "$ & 68.6 \\
\hline 25 & 6-10" & 34.5 \\
\hline 26 & $0-6^{\prime \prime}$ & 100.8 \\
\hline 26 & 6-10" & 870.4 \\
\hline 27 & $0-6 "$ & 124.5 \\
\hline 27 & 6-10" & 322.0 \\
\hline 28 & $0-6 "$ & 87.5 \\
\hline 28 & 6-10" & 73.7 \\
\hline 29 & $0-6 "$ & 253.0 \\
\hline 29 & 6-10" & 917.6 \\
\hline 30 & $0-6 "$ & 264.8 \\
\hline 30 & 6-10" & 86.9 \\
\hline 31 & $0-6 "$ & 30.3 \\
\hline 31 & 6-10" & 157.9 \\
\hline 32 & $0-6 "$ & 338.8 \\
\hline 32 & 6-10" & 263.6 \\
\hline 33 & $0-6 "$ & 112.5 \\
\hline 33 & 6-10" & 82.1 \\
\hline
\end{tabular}

* From Capital Environmental Enterprises, Inc. Location approximate. 
West Lafayette - Sagamore \& Northwestern Bridge

\begin{tabular}{|c|c|c|c|}
\hline Sample Location & Depth (in) & \begin{tabular}{|c|} 
Field Analysis \\
$\mathrm{Pb}$ Conc. (ppm)
\end{tabular} & $\begin{array}{l}\text { Lab Analysis } \\
\mathrm{Pb} \text { Conc. (ppm) }\end{array}$ \\
\hline 1 & $0-2^{\prime \prime}$ & 1819.2 & 763.6 \\
\hline 1 & $2-4 "$ & & 454.0 \\
\hline 2 & $0-2 "$ & 844.8 & 265.4 \\
\hline 2 & 2-4" & & 82.0 \\
\hline 3 & $0-2^{\prime \prime}$ & 387.4 & 147.9 \\
\hline 3 & 2-4" & & 94.4 \\
\hline 4 & $0-2 "$ & 139.4 & 96.5 \\
\hline 4 & 2-4" & & 67.5 \\
\hline 5 & $0-2 "$ & 101.0 & 96.8 \\
\hline 5 & $2-4 "$ & & 54.7 \\
\hline 6 & $0-2 "$ & 116.1 & 57.9 \\
\hline 6 & $2-4 "$ & & 63.2 \\
\hline 7 & $0-2 "$ & 72.2 & 66.6 \\
\hline 7 & $2-4 "$ & & 32.2 \\
\hline 8 & $0-2^{\prime \prime}$ & 61.7 & 78.1 \\
\hline 8 & $2-4 "$ & & 61.4 \\
\hline 9 & $0-2^{\prime \prime}$ & 60.9 & 72.3 \\
\hline 9 & $2-4 "$ & & 42.6 \\
\hline 10 & $0-2^{\prime \prime}$ & 24.6 & 56.7 \\
\hline 10 & $2-4 "$ & & 38.5 \\
\hline 11 & $0-2^{\prime \prime}$ & 379.4 & 217.4 \\
\hline 11 & 2-4" & & 229.4 \\
\hline 12 & $0-2 "$ & 350.2 & 128.7 \\
\hline 12 & 2-4" & & 133.9 \\
\hline 13 & $0-2^{\prime \prime}$ & 125.1 & 110.4 \\
\hline 13 & 2-4" & & 83.7 \\
\hline 14 & $0-2^{\prime \prime}$ & 135.4 & 301.2 \\
\hline 14 & 2-4" & & 212.6 \\
\hline 15 & $0-2 "$ & 320.2 & 274.6 \\
\hline 15 & 2-4" & & 238.8 \\
\hline 16 & $0-2 "$ & 119.5 & 124.0 \\
\hline 16 & 2-4" & & 56.1 \\
\hline 17 & $0-2^{\prime \prime}$ & 159.2 & 119.5 \\
\hline 17 & 2-4" & & 66.7 \\
\hline 18 & $0-2 "$ & 234.6 & 170.4 \\
\hline 18 & 2-4" & & 146.7 \\
\hline 19 & $0-2 "$ & 45.0 & 59.0 \\
\hline 19 & 2-4" & & 45.3 \\
\hline
\end{tabular}




\begin{tabular}{|c|c|c|c|}
\hline 20 & $0-2^{\prime \prime}$ & 72.0 & 77.4 \\
\hline 20 & $2-4^{\prime \prime}$ & & 56.8 \\
\hline 21 & $0-2^{\prime \prime}$ & 46.7 & 71.4 \\
\hline 21 & 2-4" & & 56.5 \\
\hline 22 & $0-2^{\prime \prime}$ & 191.5 & 107.4 \\
\hline 22 & $2-4^{\prime \prime}$ & & 141.5 \\
\hline 23 & $0-2^{\prime \prime}$ & 123.2 & 105.3 \\
\hline 23 & $2-4^{\prime \prime}$ & & 112.0 \\
\hline 24 & $0-2^{\prime \prime}$ & 40.7 & 62.1 \\
\hline 24 & 2-4" & & 56.2 \\
\hline 25 & $0-2^{\prime \prime}$ & 199.2 & 114.4 \\
\hline 25 & 2-4" & & 75.0 \\
\hline 26 & $0-2^{\prime \prime}$ & 82.2 & 60.5 \\
\hline 26 & $2-4^{\prime \prime}$ & & 44.7 \\
\hline 27 & $0-2^{\prime \prime}$ & 92.1 & 101.8 \\
\hline 27 & $2-4^{\prime \prime}$ & & 49.8 \\
\hline 28 & $0-2^{\prime \prime}$ & 69.9 & 52.7 \\
\hline 28 & $2-4^{\prime \prime}$ & & 49.6 \\
\hline 29 & $0-2^{\prime \prime}$ & 45.5 & 47.1 \\
\hline 29 & 2-4" & & 52.3 \\
\hline 30 & $0-2^{\prime \prime}$ & 94.1 & 83.8 \\
\hline 30 & $2-4^{\prime \prime}$ & & 38.9 \\
\hline 31 & $0-2^{\prime \prime}$ & 49.6 & 58.7 \\
\hline 31 & 2-4" & & 43.0 \\
\hline 32 & $0-2^{\prime \prime}$ & 79.8 & 83.8 \\
\hline 32 & 2-4" & & 66.8 \\
\hline 33 & $0-2^{\prime \prime}$ & 80.0 & 126.3 \\
\hline 33 & $2-4^{\prime \prime}$ & & 69.6 \\
\hline 34 & $0-2^{\prime \prime}$ & 53.8 & 60.5 \\
\hline 34 & 2-4" & & 49.0 \\
\hline 35 & $0-2^{\prime \prime}$ & 98.2 & 92.1 \\
\hline 35 & $2-4^{\prime \prime}$ & & 51.5 \\
\hline 36 & $0-2^{\prime \prime}$ & 41.6 & 48.6 \\
\hline 36 & 2-4" & & 46.0 \\
\hline 37 & $0-2^{\prime \prime}$ & 75.9 & 59.7 \\
\hline 37 & 2-4" & & 64.5 \\
\hline 38 & $0-2^{\prime \prime}$ & 34.1 & 39.9 \\
\hline 38 & 2-4" & & 29.7 \\
\hline 39 & $0-2^{\prime \prime}$ & 81.9 & 44.4 \\
\hline 39 & 2-4" & & 42.8 \\
\hline 40 & $0-2^{\prime \prime}$ & 29.5 & 41.1 \\
\hline 40 & $2-4^{\prime \prime}$ & & 33.3 \\
\hline
\end{tabular}


I-65 Total Pb Analyses.

\begin{tabular}{|c|c|c|}
\hline Sample I.D. & Depth & $\mathrm{Pb}$ (mg/kg) \\
\hline 1 & $0-2 "$ & 122 \\
\hline 1 & $2-4 "$ & 58 \\
\hline 2 & $0-2 "$ & 59 \\
\hline 2 & $2-4 "$ & 46 \\
\hline 3 & $0-2 "$ & 273 \\
\hline 3 & $2-4 "$ & 104 \\
\hline 4 & $0-2$ & 758 \\
\hline 4 & $2-4 "$ & 65 \\
\hline 5 & $0-2 "$ & 924 \\
\hline 5 & $2-4 "$ & 46 \\
\hline 6 & $0-2 "$ & 56 \\
\hline 6 & $2-4 "$ & 57 \\
\hline 7 & $0-2 "$ & 282 \\
\hline 7 & $2-4 "$ & 122 \\
\hline 8 & $0-2 "$ & 1280 \\
\hline 8 & $2-4$ & 136 \\
\hline 9 & $0-2 "$ & 1940 \\
\hline 9 & $2-4 "$ & 67 \\
\hline 10 & $0-2 "$ & 721 \\
\hline 10 & $2-4 "$ & 100 \\
\hline 11 & $0-2 "$ & 874 \\
\hline 11 & $2-4 "$ & 45 \\
\hline 12 & $0-2 "$ & 368 \\
\hline 12 & $2-4 "$ & 78 \\
\hline 13 & $0-2 "$ & 91 \\
\hline 13 & $2-4 "$ & 77 \\
\hline 14 & $0-2 "$ & 425 \\
\hline 14 & $2-4 "$ & 57 \\
\hline 15 & $0-2 "$ & 1460 \\
\hline 15 & $2-4 "$ & 73 \\
\hline 16 & $0-2 "$ & 651 \\
\hline 16 & $2-4 "$ & 203 \\
\hline 17 & $0-2 "$ & 1480 \\
\hline 17 & $2-4 "$ & 122 \\
\hline 18 & $0-2 "$ & 301 \\
\hline 18 & $2-4 "$ & 85 \\
\hline 19 & $0-2 "$ & 202 \\
\hline 19 & $2-4 "$ & 80 \\
\hline 20 & $0-2 "$ & 167 \\
\hline 20 & $2-4 "$ & 39 \\
\hline 21 & $0-2 "$ & 214 \\
\hline 21 & $2-4 "$ & 66 \\
\hline
\end{tabular}


Highway 43 Analyses.

\begin{tabular}{|c|c|c|}
\hline Sample I.D. & Depth & $\mathrm{Pb}$ (mg/kg) \\
\hline 1 & $0-2 "$ & 313 \\
\hline 1 & $2-4 "$ & 79 \\
\hline 2 & $0-2 "$ & 197 \\
\hline 2 & 2-4" & 61 \\
\hline 3 & $0-2 "$ & 103 \\
\hline 3 & 2-4" & 58 \\
\hline 4 & $0-2 "$ & 72 \\
\hline 4 & 2-4" & 38 \\
\hline 5 & $0-2 "$ & 270 \\
\hline 5 & $2-4 "$ & 170 \\
\hline 6 & $0-2 "$ & 1760 \\
\hline 6 & 2-4" & 301 \\
\hline 7 & $0-2 "$ & 1220 \\
\hline 7 & $2-4 "$ & 266 \\
\hline 8 & $0-2 "$ & 1180 \\
\hline 8 & $2-4 "$ & 113 \\
\hline 9 & $0-2 "$ & 592 \\
\hline 9 & $2-4 "$ & 143 \\
\hline 10 & $0-2 "$ & 508 \\
\hline 10 & $2-4 "$ & 86 \\
\hline 11 & $0-2 "$ & 1310 \\
\hline 11 & $2-4 "$ & 263 \\
\hline 12 & $0-2 "$ & 136 \\
\hline 12 & $2-4 "$ & 41 \\
\hline 13 & $0-2 "$ & 309 \\
\hline 13 & $2-4 "$ & 47 \\
\hline 14 & $0-2 "$ & 166 \\
\hline 14 & $2-4 "$ & 75 \\
\hline 15 & $0-2 "$ & 285 \\
\hline 15 & $2-4 "$ & 171 \\
\hline
\end{tabular}




\section{USERS' MANUAL: IMMOBILIZATION OF PB IN SOIL USING SOLUBLE PHOSPHATE}

\section{INTRODUCTION}

Contamination of soils with lead $(\mathrm{Pb})$ is fairly common. When total soil concentrations exceed $400 \mathrm{mg} / \mathrm{kg}$, the soils are unacceptable for residential use. The federal regulatory limit is 1200 $\mathrm{mg} / \mathrm{kg}$. Lead contamination can result in a variety of health affects, but of most concern is damage to young children who directly consume contaminated soil. Soils with more than 1200 $\mathrm{mg} / \mathrm{kg} \mathrm{Pb}$ are often excavated and placed in a hazardous landfill. However, soils with $\mathrm{Pb}$ contents less than twice the regulatory limits can be treated with soluble phosphate to reduce the bioavailability of the metal. Phosphate combines with the $\mathrm{Pb}$ to form relatively insoluble compounds that are less likely to allow $\mathrm{Pb}$ to enter the blood stream if the contaminated soils are consumed. For soils adjacent to highways where human exposure to the contaminated soil is limited, treatment with phosphate is an excellent alternative to excavation.

$$
5 \mathrm{~Pb}^{2+}+3 \mathrm{H}_{2} \mathrm{PO}_{4}^{-}+\mathrm{Cl}^{-} \leftrightarrow \mathrm{Pb}_{5}\left(\mathrm{PO}_{4}\right)_{3} \mathrm{Cl} \text { (chloropyromorphite) }+6 \mathrm{H}^{+}
$$

This document details the procedures for evaluation of $\mathrm{Pb}$ contamination and, when appropriate, amendment of the soil with phosphate to reduce bioavailability of the contaminant.

\section{OCCURRENCE OF PB-CONTAMINATED SOILS}

Decades of use of leaded gasoline contributed to significant elevation of $\mathrm{Pb}$ concentrations along roadsides. Concentrations of $\mathrm{Pb}$ in soils immediately adjacent to Indiana highways typically and consistently range from 200 to $400 \mathrm{mg} / \mathrm{kg}$. These concentrations diminish to background concentrations (20 to $60 \mathrm{mg} / \mathrm{kg}$ ) at distance of 2 to 10 meters from the highway. These concentrations are elevated but do not merit remedial actions.

Higher concentrations of $\mathrm{Pb}$ can be found near highways due to contamination by $\mathrm{Pb}$-laden paint, petroleum, or other products. These sites will be difficult to locate without knowledge of the contamination event, but the concentrations can be quite high, sometimes in excess of 5,000 $\mathrm{mg} / \mathrm{kg}$. Cleanup of these soils is required.

A predictable though intermittent source of $\mathrm{Pb}$ contamination along highways is surficial deposition of $\mathrm{Pb}$-based paint during the repainting of existing bridges. Concentrations in excess of $1000 \mathrm{mg} / \mathrm{kg}$ are not unusual, though the impacted areas are usually small; background levels are seen within 10 meters of the bridge.

\section{CHARACTERIZATION OF CONTAMINATED SOILS}

This section will describe the steps to be taken in characterizing the contaminated soils to determine $\mathrm{Pb}$ concentrations and the extent of the contamination.

Soil Sampling Lead contamination in soils is generally encountered only in the upper 2 to $5 \mathrm{~cm}$ ( 1 to 2 inches). Therefore, it is suggested that the soil be sampled in two stages - the upper $2 \mathrm{~cm}$ and the 2 to $5 \mathrm{~cm}$ depth. The following steps are suggested: 
1. Identify the sampling area. Systematic sampling is often preferred when little is known about the extent of contamination. Sampling points are laid out on a grid with equal spacing between each location. For bridges, soil should be sampled under the bridge structure and at points extending to $30 \mathrm{~cm}$ laterally from the bridge. Sampling points should be carefully marked with flags or measured and from a permanent reference point.

2. Obtaining soil samples. Samples should be obtained from an area roughly $10 \mathrm{~cm} \times 10$ $\mathrm{cm}$. Vegetation should be clipped down to the soil surface. Using a clean trowel or similar tool, remove samples to depths of $2 \mathrm{~cm}$. The sample should be obtained by

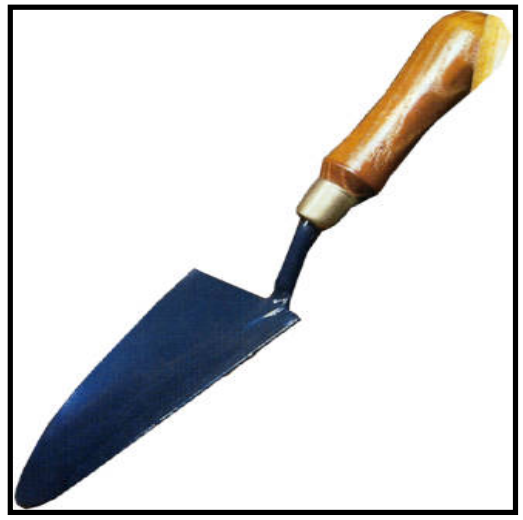

Figure 1. Typical trowel for soil sampling. removing the soil to a uniform depth throughout the subsampling area. (That is, do not simply thrust the trowel into the soil at an angle to a depth of $2 \mathrm{~cm}$.) Ideally, a rectangle of soil will be removed that is $10 \times 10 \times 2 \mathrm{~cm}$ deep. Roots, stones, and other debris should be separated from the soil. The soil sample should be stored in a sealable bag; zipperlocked quart-sized freezer bags are ideal. Samples of soil to be tested for $\mathrm{Pb}$ do not have to be kept frozen or cold. However, storage of the samples in a hard-sided cooler is advisable to avoid damage to the samples during transport.

3. Soil preparation and analysis. If the soil analysis will be done in-house, the soil should be digested in acid followed by atomic absorption or inductively coupled plasma analysis (ASTM, 1998b). In the absence of such facilities, it is recommended that a US EPA certified laboratory for soil analysis be identified, and the soils should be shipped to this lab for analysis. In either case, soil preparation should consist of mixing the sample thoroughly to ensure homogeneity, and all debris should be removed. In some cases, it may be desirable to include air drying the soil for 48 hours followed by grinding and sieving to pass a $2 \mathrm{~mm}$ (10 mesh) screen. This process ensures a well mixed sample.

4. Interpreting the data. Background $\mathrm{Pb}$ concentrations in soil are generally less than 100 $\mathrm{mg} / \mathrm{kg}$, but $\mathrm{Pb}$ in the soil is not considered to be a problem until concentrations exceed $400 \mathrm{mg} / \mathrm{kg}$. Thus, purpose of the sampling and analysis is to delineate those areas where $400 \mathrm{mg} / \mathrm{kg}$ is exceeded. Therefore, a map of concentrations should be made and the areas identified with excessive $\mathrm{Pb}$ concentrations. (Concentrations greater than $2000 \mathrm{mg} / \mathrm{kg}$ may require special treatment and notification of regulatory agencies.)

The figure below is an actual sampling pattern and total $\mathrm{Pb}$ concentrations for an Indiana bridge. Superimposed on this map is a shaded area which represents the approximate delineation of the soil area that should include all areas with $\mathrm{Pb} \geq 400 \mathrm{mg} / \mathrm{kg}$. 


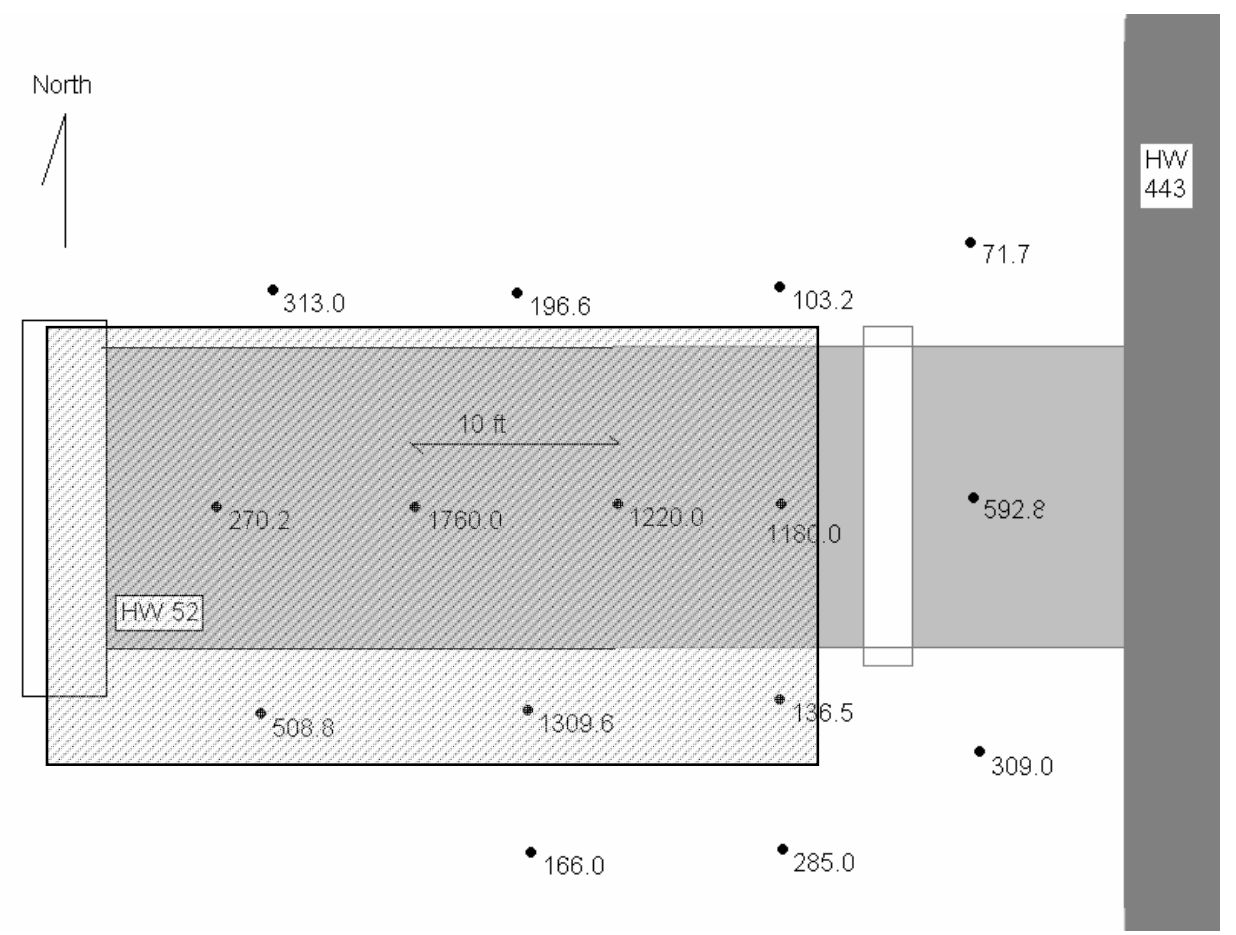

Figure 2. Sample design and resulting total $\mathrm{Pb}$ concentrations. The cross-hatching is the approximate area in which $\mathrm{Pb}>400 \mathrm{mg} / \mathrm{kg}$.

\section{TREATING THE Pb-CONTAMINATED AREA WITH SOLUBLE PHOSPHATE}

1. Calculating the required phosphorus. After the soil has been characterized and determined to be contaminated with $\mathrm{Pb}$, the next step is to quantify the amount of soluble phosphorus to be added to the soil. The recommendation is to add phosphorus at a $3: 1$ mole ratio to ensure complete reaction. After making the various conversions from $\mathrm{mg}$ $\mathrm{Pb} / \mathrm{kg}$ soil (ppm Pb), the following equation is used to determine the amount of $\mathrm{P}$ fertilizer to be added for a $1000 \mathrm{ft}^{2}$ area to be treated to a depth of $1 \mathrm{inch}$ :

$\mathrm{lb}$ fertilizer per $1000 \mathrm{ft}^{2}=\left[(\mathrm{x} \mathrm{mg} \mathrm{Pb} / \mathrm{kg}\right.$ soil $\left.) *(0.00701) /\left(\% \mathrm{P}_{2} \mathrm{O}_{5} / 100\right)\right]$

The $\% \mathrm{P}_{2} \mathrm{O}_{5}$ is the fertilizer analysis. For example, a bag of fertilizer marked 18-46-0 has $18 \% \mathrm{~N}, 46 \% \mathrm{P}_{2} \mathrm{O}_{5}$, and $0 \mathrm{~K}_{2} \mathrm{O}$; for this fertilizer, $\% \mathrm{P}_{2} \mathrm{O}_{5} / 100=46 / 100=0.46$. So, if we assume that the average $\mathrm{Pb}$ content of the soil was $1000 \mathrm{mg} / \mathrm{kg}$ and we are using 18-46-0 fertilizer, we would need

$\mathrm{lb}$ fertilizer per $1000 \mathrm{ft}^{2}=(1000 \mathrm{mg} \mathrm{Pb} / \mathrm{kg}$ soil $) *(0.0071) / 0.46$

$\mathrm{lb}$ fertilizer per $1000 \mathrm{ft}^{2}=15.4$ 
Thus, 15.4 lbs of fertilizer should be applied as described below. The amount of fertilizer should to be adjusted for different areas or if the $\mathrm{Pb}$ contamination is greater than 1 inch deep.

2. Application of the fertilizer. Under ideal circumstances, the fertilizer as a solution should be mixed thoroughly with the soil. This is not always practical, so adjustments may need

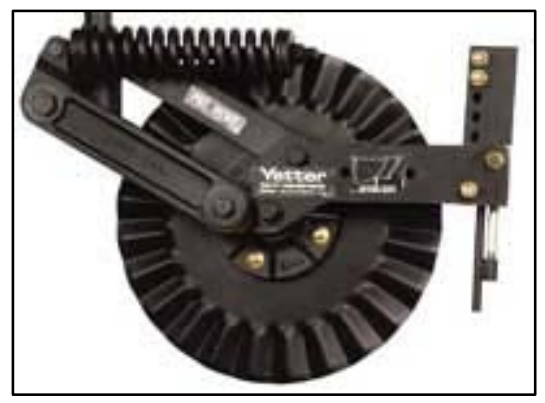

Figure 3. Typical fertilizer injection attachment. to be made according to the circumstances. If the soil is bare, spraying a fertilizer solution followed by tilling to the proper depth would be an excellent approach. However, if the area to be treated is on a slope or if the existing vegetation is to be preserved, other options are available. A good option would be to inject a fertilizer solution or solid into the soil to the proper depth. The system shown below is a typical injector system used in agriculture. If this (or something similar) is not available, pelletized fertilizer may be broadcast on the surface of the soil. Raking the fertilizer into the soil is recommended to increase

the contact between the soil and the fertilizer and to ensure rapid and complete reaction to produce the desired product, chloropyromorphite.

\section{ASSESSMENT AND MONITORING}

In some instances, monitoring of the site and further soil testing may be required. The total $\mathrm{Pb}$ content should not change, although concentrations may sometimes decrease from mixing the contaminated surface soil with the uncontaminated subsurface. Although total $\mathrm{Pb}$ will be theoretically invariant, the addition of soluble phosphate will decrease the $\mathrm{Pb}$ indexes when evaluated by standard techniques. The most common test is the Toxicity Characteristic Leaching Procedure (TCLP). For solid waste, the maximum allowable TCLP value for solid waste is 5 ppm to ensure that $\mathrm{Pb}$ will not leach from the material. If this or a similar evaluation procedure is necessary, the soil of the contaminated area should be sampled as described above and submitted for TCLP testing. 


\section{REFERENCES}

ASTM. 1998c. ASTM E 1645. Standard practice for the preparation of dried paint samples for subsequent lead analysis by atomic spectrometry. American Society for Testing and Materials.

TCLP. http://www.epa.gov/epaoswer/hazwaste/test/pdfs/1311.pdf, modified version from Jinling Zhuang (personal communication). 